\title{
High Temperature Mass Spectrometric Study of Thermodynamic Properties and Vaporization Processes of Oxide Systems: Experiment and Modeling
}

\author{
V.L. Stolyarova* \\ Chemical Department, Saint Petersburg State University, Universitetsky pr. 26, p/o Stary Petergof, 198504 St. \\ Petersburg, Russia
}

\begin{abstract}
The unique opportunities and features of high temperature mass spectrometric method for study vaporization processes and thermodynamic properties of oxide systems and materials (glasses, ceramics and coatings) were considered. Various types of vapour species were found over oxide systems studied such as the associated, dissociated and polymerized products of vaporization. The regularities of the vaporization of the binary and multicomponent oxide systems according to the position of oxide modifier in the Periodic table of atoms were illustrated and discussed from the point of view of the acid-base concept. Results on determination of thermodynamic functions in oxide systems were considered taking into account the main requirements for the confirmation of their reliability. Thermodynamic functions of oxide systems studied showed various signs of the deviations from the ideality. The general lattice theory of associated solutions was used for the calculation of thermodynamic properties of the ternary silicate melts studied. Based on this theory the correlation between thermodynamic functions obtained in the systems under consideration and the number of various types of bonds formed in these melts was illustrated. Using this approach the different levels of deviations from the ideality in the melts studied were clarified. Examples of the practical applications of high temperature mass spectrometry for developing advanced materials were shown.
\end{abstract}

Keywords: Review, Knudsen Effusion Mass Spectrometry (KEMS), Thermochemistry, Phase equilibrium, High temperature, Vaporisation, Modelling, Metal oxide systems.

\section{INTRODUCTION}

One of the important requirements for the scientific invention of new oxide materials such as glasses, ceramics and coatings are to be able to combine the thermodynamic and crystal chemistry approaches, taking into account condensed-phase vapour equilibriums. Such information is necessary not only to choose the correct composition of material to be used in given industrial conditions, but also to conduct effectively the processes of forming, sintering and product making. High temperature mass spectrometry is one of the most informative methods of high-temperature chemistry along with calorimetry and electromotive force measurements. The method enables one not only to determine thermodynamic properties of components in both condensed and gaseous phases but to identify the composition of vapours. Advantages of the Knudsen effusion mass spectrometric method for the investigations of thermodynamic properties and vaporization processes at high temperatures in particular oxide systems and materials were considered in details in [1].

The following tasks of the critical technologies of the Russian Federation may be solved using information on

*Address correspondence to this author at the Chemical Department, Saint Petersburg State University, Universitetsky pr. 26, p/o Stary Petergof, 198504 St. Petersburg, Russia; Tel: +7-812-428-40-67;

Fax: +7-812-428-69-39; E-mail: stv108@inbox.ru vaporization processes and thermodynamic properties of oxide systems and materials obtained by high temperature mass spectrometric method:

- nanotechnologies and technologies of creation of nanomaterials;

- technologies of nuclear energetic, nuclear fuel cycle, safety handling of nuclear wastes and the return nuclear fuel;

- technologies of remaking and utilization of mancaused formations and wastes;

- technologies of decreasing of risks and consequences of natural and man-caused disasters;

- technologies of preparation and manufacturing of composite materials and ceramics;

- technologies of preparation of new generation of the space rocket, aircraft and navy engineering;

- basic and critical military, special and industrial technologies;

- technologies of creation of the electronic component base.

It should be mentioned the wide potential abilities of high temperature mass spectrometry to study the vaporization processes and thermodynamic properties in the following high temperature processes such as 
- $\quad$ preparation and exploiting of glasses, ceramics, films, coatings;

- preparation of refractory materials and materials for microelectronics;

- consideration of the materials stability in the various gaseous atmospheres;

- the chemical processes in the energetic plants, including the nuclear power plants;

- the optimization of the utilization processes of wastes;

- processes of preventing of pollution of the environment;

- geo- and astrochemical processes;

- the metallurgical processes and some others.

It should be underlined also that the high temperature mass spectrometric method allows obtaining the unique thermodynamic information at high temperatures that is crucial for prediction and modeling of physicochemical properties of oxide materials based on statistical thermodynamic and semi-empirical approaches. That is why the purpose of the present paper is the consideration of the main information on the vaporization processes and thermodynamic properties obtained by high temperature mass spectrometry as well as the statistical thermodynamic approaches used for modeling in oxide systems in particular in glasses and melts.

Oxide systems that will be the main topic of the consideration in the present review are the base of a lot of oxide materials with the extremely wide spectra of their application. Between them are the following:

- glasses, ceramics, pyroceramics;

- $\quad$ slags in non-ferrous and ferrous metallurgy;

- coatings with the heat control of the space aircrafts;

- $\quad$ the generators and indicators of the hypersonic waves in solids;

- the spatio-temporal light modulators;

- the scintillator of the hard $\gamma$-radiation;

- $\quad$ the thin films condensers;

- the phosphors and many others.

There was the most interesting between the various types of oxide systems studied the consideration of high temperature behaviour of the borosilicate systems. Because they also illustrated the wide ranges of applications in the modern material science and technologies such as for the incorporation of nuclear wastes, for obtaining metals from slags in metallurgy, for preparation the special glasses:

- $\quad$ with low melting point;

- with high refractive index;

- $\quad$ with high dispersion coefficient;

- with high radiotransparency;
- $\quad$ with the effective absorbtion of the slow neutrons.

The previous results on the mass spectrometric studies of the vaporization processes and thermodynamic properties of oxide systems and materials were summarized in the monograph [1] and reviews [2-10].

As to the subjects of investigations as binary and multicomponent borate, germanate, phosphate and silicate systems as well as the unique information on vaporization processes and thermodynamic properties at high temperatures the publications mentioned [1-10] still have the pioneer character including the mass spectrometric approaches for study thermodynamic functions of components in these systems at condensed phase. Only some of there results were reproduced recently in USA, France, Germany and Japan [1, 4, 5]. Even from the first steps of these studies these results on the vaporization processes and thermodynamic properties of glasses and melts in the $\mathrm{Na}_{2} \mathrm{O}$ $\mathrm{B}_{2} \mathrm{O}_{3}-\mathrm{GeO}_{2}$ system $[11,12]$ had the wide scientific resonance. It was shown, for example, that the obtained thermodynamic properties of glasses and melts in the $\mathrm{B}_{2} \mathrm{O}_{3}$ $\mathrm{GeO}_{2}$ system [13] were in agreement with the information on the structure of its condensed phases accepted based on the results on the investigations of their density, viscosity, refractive index, by IR-spectroscopy and NMR method. Thermodynamic properties of the $\mathrm{B}_{2} \mathrm{O}_{3}-\mathrm{GeO}_{2}$ system at high temperatures [13] were used in [14] for the calculation of its phase diagram and even now this is the only available information on the phase equilibriums in this system.

Present review is summarized the results on the vaporization processes and thermodynamic properties of ternary silicate melts obtained mainly during last ten years using high temperature mass spectrometric method. The systems under consideration have the great importance in the various fields of high temperature material chemistry and technologies such as glass, ceramics, coatings production, metallurgy, geochemistry, nuclear and space technologies and some others. Information on the vaporization processes and thermodynamic properties of the following ternary silicate systems $\mathrm{Na}_{2} \mathrm{O}-\mathrm{B}_{2} \mathrm{O}_{3}-\mathrm{SiO}_{2}, \mathrm{Cs}_{2} \mathrm{O}-\mathrm{B}_{2} \mathrm{O}_{3}-\mathrm{SiO}_{2}, \mathrm{Rb}_{2} \mathrm{O}-$ $\mathrm{B}_{2} \mathrm{O}_{3}-\mathrm{SiO}_{2}, \mathrm{MgO}-\mathrm{B}_{2} \mathrm{O}_{3}-\mathrm{SiO}_{2}, \mathrm{CaO}-\mathrm{B}_{2} \mathrm{O}_{3}-\mathrm{SiO}_{2}, \mathrm{SrO}-\mathrm{B}_{2} \mathrm{O}_{3}-$ $\mathrm{SiO}_{2}, \mathrm{BaO}-\mathrm{B}_{2} \mathrm{O}_{3}-\mathrm{SiO}_{2}, \mathrm{MgO}-\mathrm{Al}_{2} \mathrm{O}_{3}-\mathrm{SiO}_{2}, \mathrm{CaO}-\mathrm{Al}_{2} \mathrm{O}_{3}-\mathrm{SiO}_{2}$, $\mathrm{CaO}-\mathrm{TiO}_{2}-\mathrm{SiO}_{2}$ and $\mathrm{BaO}-\mathrm{TiO}_{2}-\mathrm{SiO}_{2}$ together with the earlier obtained data [1-10] is discussed.

\section{VAPORIZATION FEATURES OF OXIDE SYSTEMS}

The variety of the vapour species with different volatilities, identified over oxide systems, is one of the reasons that narrows their use at high temperatures, especially during interaction processes with the other materials.

The method of a high temperature mass spectrometry [1] allows to identify a composition of a gas phase, to determine partial pressures and enthalpies of vaporization of components, and also such thermodynamic functions of systems, as activities and chemical potentials of components, Gibbs energies and the relevant excess quantities.

Using high temperature mass spectrometric method it was illustrated that in vapour over oxide systems various types of species may be identified such as associates, polymers and the products of dissociation processes [1]. 
Passing from the regularities of vaporization of individual oxides [8] to oxide systems, the absolute value of the sublimation (or vaporization) enthalpy of the components may increase when there are positive deviations from ideality (as is the case in melts of the $\mathrm{B}_{2} \mathrm{O}_{3}-\mathrm{GeO}_{2}, \mathrm{~B}_{2} \mathrm{O}_{3}$ $\mathrm{GeO}_{2}-\mathrm{SiO}_{2}$ and $\mathrm{GeO}_{2}-\mathrm{SiO}_{2}$ systems) or a decrease, when there are negative divergences from ideality (e.g. in the melts of the $\mathrm{Na}_{2} \mathrm{O}-\mathrm{SiO}_{2}, \mathrm{Na}_{2} \mathrm{O}-\mathrm{B}_{2} \mathrm{O}_{3}$ and $\mathrm{B}_{2} \mathrm{O}_{3}-\mathrm{SiO}_{2}$ systems). For this reason, in the course of the vaporization of oxide melts, one can observe both dissociation and polymerization of molecular forms of the vapour.

Vaporization of silicate, germanate, borate and phosphate melts, in addition to the processes of polymerization and dissociation, is also accompanied by the association of vapour molecular forms, which leads to the identification of new compounds in the gas phase. The formation of such compounds is due to various factors, including the interaction of oxides in the condensed or gas phase.

The vapour composition over the binary phosphate, borate and silicate systems identified by high temperature mass spectrometric method was summarized and grouped according to the number of outer valence electrons of an oxide modifier $[4,8,15]$. This consideration was carried out at high temperatures, when the partial pressures of the vapour species were in the ranges $10^{-9}-10^{-4}$ bar. It was shown that the relative volatility and the character of the vaporization processes of the binary oxide systems are in agreement with the decrease of the relative volatility of individual oxides of $\mathrm{P}_{2} \mathrm{O}_{5}, \mathrm{~B}_{2} \mathrm{O}_{3}$ and $\mathrm{SiO}_{2}$. More complicated associated vapour species over oxide systems were observed as the result of the increase of the atom masses oxidemodifiers in the rows of the Periodic Table. This fact may be connected with the participation of $\mathrm{d}$ - and f- electrons in the chemical bonds and the penetration of the s-electrons under the cover of the $3 \mathrm{~d}-, 4 \mathrm{~d}-, 4 \mathrm{f}-$ and $5 \mathrm{~d}-$ electrons.

Earlier it was illustrated [4] also that the deviations from the ideality of the $\mathrm{P}_{2} \mathrm{O}_{5}, \mathrm{~B}_{2} \mathrm{O}_{3}$ and $\mathrm{SiO}_{2}$ chemical potentials as a function of the content of oxide modifier in the series of the corresponding binary systems were in agreement with the variety of vaporization processes of their components, such as dissociation, association and polymerization. The following parameters were taken into account to understand the vaporization character of the binary oxide systems from the point of view of the acid-base concept $[15,16]$ :

- values of the differences of electron potentials, forming oxides;

- $\quad$ enthalpies of formation of the oxide modifier;

- the lattice energy of the oxide modifier per mole of $\mathrm{O}^{-}$ 2 at $298 \mathrm{~K}$;

- the energies of the $\mathrm{M}-\mathrm{O}-\mathrm{X}$ bond ( $\mathrm{X}=\mathrm{P}, \mathrm{B}, \mathrm{Si}$ ).

The associated gaseous molecules were found over binary phosphate, borate and silicate systems with the same relative volatility of the individual oxides and the differences of the electron potentials, forming oxides in the binary systems, more than $0.8 \mathrm{eV} / \mathrm{pm}$. Taking into consideration the observed regularities of the vaporization of oxide systems, the existence of the associated gaseous molecules might be expected and discussed over the $\mathrm{FeO}-\mathrm{B}_{2} \mathrm{O}_{3}, \mathrm{SrO}-\mathrm{B}_{2} \mathrm{O}_{3}$ and
${\mathrm{BaO}-\mathrm{SiO}_{2}}_{2}$ systems. Such composition of vapour was confirmed recently over two last systems [17]. The associated vapour species over binary borate and silicate systems were observed as a result of the decrease of the lattice energy of the oxides; the increase of the enthalpy of formation of the individual oxides and the negligible changes in the values of the M-O-B and $\mathrm{M}-\mathrm{O}-\mathrm{Si}$ bond energies compared with the same values in the individual oxides $\left(\mathrm{B}_{2} \mathrm{O}_{3}\right.$ and $\left.\mathrm{SiO}_{2}\right)$ in the periods of the Periodic Table. In the case of the phosphate systems the energy of the M-O-P bond was lower than the value of the energy of the P-O-P bond in phosphorus oxide. This might be one of the reasons why the quantity of the associated vapour species over phosphate systems was predominant compared with the relative quantity of the polymerized species over borate systems. The increase of the volatility in the binary systems in the rows of the System and the predominance of the dissociative forms in vapour were connected with the increase of the lattice energy of the individual oxides, the decrease of the enthalpy of formation of the individual oxides and the decrease of the differences of the electron potentials of oxides forming binary oxide systems. Despite the complex vapour composition over the oxide systems, the order of their relative volatility at constant temperatures was in agreement with the main regularities, observed earlier for the other types of inorganic compounds: the increase of the relative volatility of the systems from the first to the sixth period and its decrease from the first to the sixth group of the Periodic Table.

The question on formation of the dimer molecules in vapour over binary and multicomponent systems and its dependence from the temperature may be clear from the consideration [8].

It was found that the changes of the chemical potentials of oxides and Gibbs energies in glasses and melts of glassforming systems to a great extent due to interactions of an acid-base nature were in agreement of the relative changes of bonds energies of mixed type that form in the melts of the above systems [18].

The correlation of the values of the maximum differences of electron potentials of the elements that form oxides in binary systems, from which multicomponent melts can be composed, with the information on the occurrence of gaseous monomers of borates and their dimers in the vapour over them, makes it possible to predict, to the first approximation, the tendency to association and polymerization of oxides in the vapour over multicomponent systems. The suggested criterion, however, requires additional discussion.

From the point of view of the acid-base concept $[1,3,19]$ the following major factors should be taken into consideration when comparing the volatility of oxide systems:

a. the relationship of the partial pressures of molecular forms in the vapour over individual oxides (volatility of oxides) forming a system under isothermal conditions;

b. the relative content (concentration) of oxides in the condensed phase of a multicomponent system;

c. the tendency of molecular forms of the gaseous phase of oxide pairs forming a multicomponent system to 
Table 1. Composition of Vapour Over the Ternary Silicate Systems Studied [8-10, 22-36].

\begin{tabular}{|c|c|c|c|}
\hline System & $\mathbf{T}, \mathbf{K}$ & Composition of Vapour Over Systems Studied & References \\
\hline \hline $\mathrm{Na}_{2} \mathrm{O}-\mathrm{B}_{2} \mathrm{O}_{3}-\mathrm{SiO}_{2}$ & 1200 & $\mathrm{NaBO}_{2},\left(\mathrm{NaBO}_{2}\right)_{2}, \mathrm{~B}_{2} \mathrm{O}_{3}$ & {$[22,23]$} \\
\hline $\mathrm{Cs}_{2} \mathrm{O}-\mathrm{B}_{2} \mathrm{O}_{3}-\mathrm{SiO}_{2}$ & 1020 & $\mathrm{CsBO}_{2},\left(\mathrm{CsBO}_{2}\right)_{2}, \mathrm{~B}_{2} \mathrm{O}_{3}$ & {$[9,24]$} \\
\hline $\mathrm{Rb}_{2} \mathrm{O}-\mathrm{B}_{2} \mathrm{O}_{3}-\mathrm{SiO}_{2}$ & 900 & $\mathrm{RbBO}_{2},\left(\mathrm{RbBO}_{2}\right)_{2}, \mathrm{~B}_{2} \mathrm{O}_{3}$ & {$[25]$} \\
\hline $\mathrm{MgO}-\mathrm{B}_{2} \mathrm{O}_{3}-\mathrm{SiO}_{2}$ & $1550-1800$ & $\mathrm{MgBO}_{2}, \mathrm{MgB}_{2} \mathrm{O}_{4}, \mathrm{~B}_{2} \mathrm{O}_{3}, \mathrm{SiO}, \mathrm{O}_{2}$ & {$[10]$} \\
\hline $\mathrm{CaO}-\mathrm{B}_{2} \mathrm{O}_{3}-\mathrm{SiO}_{2}$ & 1800 & $\mathrm{CaBO}_{2}, \mathrm{CaB}_{2} \mathrm{O}_{4}, \mathrm{~B}_{2} \mathrm{O}_{3}, \mathrm{SiO}, \mathrm{O}_{2}$ & {$[26,27]$} \\
\hline $\mathrm{SrO}-\mathrm{B}_{2} \mathrm{O}_{3}-\mathrm{SiO}_{2}$ & 1720 & $\mathrm{SrBO}_{2}, \mathrm{SrB}_{2} \mathrm{O}_{4}, \mathrm{~B}_{2} \mathrm{O}_{3}, \mathrm{SiO}, \mathrm{O}_{2}$ & {$[27,28]$} \\
\hline $\mathrm{BaO}-\mathrm{B}_{2} \mathrm{O}_{3}-\mathrm{SiO}_{2}$ & 1650 & $\mathrm{BaBO}_{2}, \mathrm{BaB}_{2} \mathrm{O}_{4}, \mathrm{~B}_{2} \mathrm{O}_{3}, \mathrm{SiO}, \mathrm{O}_{2}$ & {$[27,29,30]$} \\
\hline $\mathrm{MgO}-\mathrm{Al}_{2} \mathrm{O}_{3}-\mathrm{SiO}_{2}$ & $1770-1940$ & $\mathrm{Mg}, \mathrm{SiO}, \mathrm{O}_{2}$ & {$[9]$} \\
\hline $\mathrm{CaO}-\mathrm{Al}_{2} \mathrm{O}_{3}-\mathrm{SiO}_{2}$ & $1800-2000$ & $\mathrm{Ca}, \mathrm{CaO}, \mathrm{CaSiO}$ & $\mathrm{AlSiO}, \mathrm{Al}, \mathrm{AlO}, \mathrm{SiO}, \mathrm{O}_{2}$ \\
\hline $\mathrm{CaO}-\mathrm{TiO}_{2}-\mathrm{SiO}_{2}$ & $1800-2000$ & $\mathrm{Ca}, \mathrm{CaO}, \mathrm{TiO}_{2}, \mathrm{TiO}, \mathrm{SiO}, \mathrm{O}_{2}$ & {$[8,31-33]$} \\
\hline $\mathrm{BaO}-\mathrm{TiO}_{2}-\mathrm{SiO}_{2}$ & $1800-2000$ & $\mathrm{Ba}, \mathrm{BaO}, \mathrm{TiO}_{2}, \mathrm{TiO}, \mathrm{SiO}, \mathrm{O}_{2}$ & {$[8,33-35]$} \\
\hline
\end{tabular}

association, one of the criteria determining this being the differences of electron potentials of the elements forming the oxides;

d. the values of oxygen partial pressures characterizing the acid-base properties of oxide melts which are determined by their relative volatilities, allowing the most probable processes of the vaporization of components to be estimated.

The availability of the data obtained by the high temperature mass spectrometric technique concerning the thermodynamic properties of glass forming oxide melts in conjunction with the values of electron potentials of elements forming the oxides, made it possible to reveal the principal regularities of their vaporization.

The main factors for the prediction of the relative volatility of the binary and multicomponent glass forming systems were considered based on the data on the composition of vapour and thermodynamic properties obtained by the high temperature mass spectrometric method. They were as follows:

with the same oxide modifier, one can observe the increase of volatility of components in the order from silicate and germanate to borate and phosphate melts, as a consequence of the increase of acidity of the melts in the order indicated;

predominant species in the vapour over germanate and silicate glass forming melts were the forms which were characteristic of dissociation vaporization of the oxides forming the systems;

in the vapour over borate melts containing oxides of alkali metals and of beryllium, lead, bismuth or barium, the formation of gaseous borates was most probable, their polymerization also was possible;

in multicomponent alkali metal boro-silicate and germanate melts with a higher content of boron oxide than of the oxides of alkali metals and silica, alkali metal monomer of borates were the main vapour species.

The approach discussed for the evaluation of the vapour composition over multicomponent oxide glasses and melts was successfully confirmed in the prediction of the vaporization processes in the systems presented in $[8,20]$ as the example and used for the comparison of the relative volatilities of various glasses [21].

In agreement with the regularities of the vaporization of oxide systems mentioned above there was the composition of vapour over the glasses, ceramics and melts in the $\mathrm{Na}_{2} \mathrm{O}-\mathrm{B}_{2} \mathrm{O}_{3}$ $\mathrm{SiO}_{2}[22,23], \mathrm{Cs}_{2} \mathrm{O}-\mathrm{B}_{2} \mathrm{O}_{3}-\mathrm{SiO}_{2}[9,24], \mathrm{Rb}_{2} \mathrm{O}-\mathrm{B}_{2} \mathrm{O}_{3}-\mathrm{SiO}_{2}$ [25], $\mathrm{MgO}-\mathrm{B}_{2} \mathrm{O}_{3}-\mathrm{SiO}_{2}[10], \mathrm{CaO}-\mathrm{B}_{2} \mathrm{O}_{3}-\mathrm{SiO}_{2}[26,27], \mathrm{SrO}-\mathrm{B}_{2} \mathrm{O}_{3}-\mathrm{SiO}_{2}$ $[27,28], \mathrm{BaO}-\mathrm{B}_{2} \mathrm{O}_{3}-\mathrm{SiO}_{2}$ [27, 29, 30], $\mathrm{MgO}-\mathrm{Al}_{2} \mathrm{O}_{3}-\mathrm{SiO}_{2}$ [9], $\mathrm{CaO}-\mathrm{Al}_{2} \mathrm{O}_{3}-\mathrm{SiO}_{2}$ [8, 31-33], $\mathrm{CaO}-\mathrm{TiO}_{2}-\mathrm{SiO}_{2}$ [8, 33-35], BaO$\mathrm{TiO}_{2}-\mathrm{SiO}_{2}[8,33,36]$ systems summarized in Table 1.

Using traditional high temperature mass spectrometric approach it was shown that in the temperature range 1600$2000 \mathrm{~K}$ the vaporization processes over the samples of the $\mathrm{MgO}-\mathrm{Al}_{2} \mathrm{O}_{3}-\mathrm{SiO}_{2}, \quad \mathrm{CaO}-\mathrm{Al}_{2} \mathrm{O}_{3}-\mathrm{SiO}_{2}, \mathrm{CaO}-\mathrm{TiO}_{2}-\mathrm{SiO}_{2}$ and $\mathrm{BaO}-\mathrm{TiO}_{2}-\mathrm{SiO}_{2}$ systems are the similar to the transition to the gaseous phase of the corresponding individual oxides. As to the glasses and melts of the $\mathrm{Na}_{2} \mathrm{O}-\mathrm{B}_{2} \mathrm{O}_{3}-\mathrm{SiO}_{2}, \mathrm{Cs}_{2} \mathrm{O}-\mathrm{B}_{2} \mathrm{O}_{3}-$ $\mathrm{SiO}_{2}, \mathrm{Rb}_{2} \mathrm{O}-\mathrm{B}_{2} \mathrm{O}_{3}-\mathrm{SiO}_{2}, \mathrm{MgO}-\mathrm{B}_{2} \mathrm{O}_{3}-\mathrm{SiO}_{2}, \mathrm{CaO}-\mathrm{B}_{2} \mathrm{O}_{3}-\mathrm{SiO}_{2}$, $\mathrm{SrO}-\mathrm{B}_{2} \mathrm{O}_{3}-\mathrm{SiO}_{2}, \mathrm{BaO}-\mathrm{B}_{2} \mathrm{O}_{3}-\mathrm{SiO}_{2}$ systems in addition to the vaporization of individual oxides the corresponding monomers and dimmers of borates were identified in vapour as well as gaseous silicates.

Various types of vapour species were found over these ternary silicate systems studied such as the associated, dissociated and polymerized products of vaporization. It was shown also that the content of vapour over these systems was in agreement with the composition of the gaseous phase over the corresponding binary systems.

\section{THERMODYNAMIC DATA OF OXIDE SYSTEMS STUDIED BY HIGH TEMPERATURE MASS SPECTROMETRIC METHOD}

Thermodynamic properties of the binary and multicomponent oxide systems such as activities and chemical potentials of components, the Gibbs energies and the partial and integral enthalpies of mixing obtained by high temperature mass spectrometric method were discussed in detail in [1-3].

In all experimental studies mentioned [1-36] a lot of attention was given to the accuracy and the reliability of thermodynamic data obtained by high temperature mass spectrometric method in the binary and multicomponent oxide systems under investigations. 
Because of this reason it was traditional approach when all thermodynamic functions obtained in oxide systems by the method mentioned were considered

- from the point of view of the necessary stability conditions as regards the continuous nature its change of state;

- $\quad$ as the verification of the mutual agreement of the data using the Gibbs-Duhem equation;

- as the examination of the mutual agreement of the results using various experimental methods of high temperature chemistry (EMF, the exchange equilibriums in slags, the sulphide capacity method, the high temperature solution calorimetry, the ionmolecular equilibrium method) as well as the procedures of high temperature mass spectrometry (the dimer-monomer method, the Belton-Fruehan and Wagner methods, the ion current comparison method);

- as the correlation with the information on phase diagrams of the system studied.

The variety of results of such approach for obtaining the reliable experimental thermodynamic data by high temperature mass spectrometry in oxide systems may be found in [1-3]. Thermodynamic regularities and reliability of high temperature mass spectrometric data for glass-forming oxide systems were considered also in [37]. The advantages of application of the Belton-Fruehan method to study the thermodynamic functions of oxide systems were illustrated in details in [38]. The correlation of thermodynamic properties obtained by high temperature mass spectrometry with the information on phase diagrams of the system studied was shown for example in the following systems $\mathrm{CaO}-\mathrm{SiO}_{2}$ [39], $\mathrm{GeO}_{2}-\mathrm{P}_{2} \mathrm{O}_{5}$ [40], $\mathrm{B}_{2} \mathrm{O}_{3}-\mathrm{Al}_{2} \mathrm{O}_{3}$ [41], $\mathrm{Al}_{2} \mathrm{O}_{3}$ $\mathrm{SiO}_{2}$ [42- 44] and $\mathrm{MgO}-\mathrm{SiO}_{2}[45]$.

Such detail and systematic consideration of the experimental data obtained by high temperature mass spectrometry in oxide systems was the base of using the values found in the Russian data base "Metallurgy" [46].

Thermodynamic functions of the systems under consideration such as activities and chemical potentials of components as well as the Gibbs energies showed various signs of the deviations from the ideal behaviour. The features of thermodynamic description of the melts in the following systems studied recently may be found also as mentioned above for the $\mathrm{Na}_{2} \mathrm{O}-\mathrm{B}_{2} \mathrm{O}_{3}-\mathrm{SiO}_{2}[22,23], \mathrm{Cs}_{2} \mathrm{O}-\mathrm{B}_{2} \mathrm{O}_{3}-\mathrm{SiO}_{2}$ [9, 24], $\mathrm{Rb}_{2} \mathrm{O}-\mathrm{B}_{2} \mathrm{O}_{3}-\mathrm{SiO}_{2}$ [25], $\mathrm{MgO}-\mathrm{B}_{2} \mathrm{O}_{3}-\mathrm{SiO}_{2}$ [10], $\mathrm{CaO}-$ $\mathrm{B}_{2} \mathrm{O}_{3}-\mathrm{SiO}_{2}$ [26, 27], $\mathrm{SrO}-\mathrm{B}_{2} \mathrm{O}_{3}-\mathrm{SiO}_{2}$ [27, 28], $\mathrm{BaO}-\mathrm{B}_{2} \mathrm{O}_{3}-$ $\mathrm{SiO}_{2}[27,29,30], \mathrm{MgO}-\mathrm{Al}_{2} \mathrm{O}_{3}-\mathrm{SiO}_{2}[9], \mathrm{CaO}-\mathrm{Al}_{2} \mathrm{O}_{3}-\mathrm{SiO}_{2}$ [8, 31-33], $\mathrm{CaO}-\mathrm{TiO}_{2}-\mathrm{SiO}_{2}[8,33-35], \mathrm{BaO}-\mathrm{TiO}_{2}-\mathrm{SiO}_{2}[8,33$, 36] systems. The negative deviations from the ideal behaviour were observed in the melts of all these systems except $\mathrm{CaO}-\mathrm{TiO}_{2}-\mathrm{SiO}_{2}$ and $\mathrm{BaO}-\mathrm{TiO}_{2}-\mathrm{SiO}_{2}$ glasses and melts where the existence of the wide immiscibility regions may be expected as in the $\mathrm{TiO}_{2}-\mathrm{SiO}_{2}$ system according to [47].

As the examples of the thermodynamic data obtained Figs. (1-5) illustrate the thermodynamic information found first for the melts in the $\mathrm{MgO}-\mathrm{B}_{2} \mathrm{O}_{3}-\mathrm{SiO}_{2}$ and $\mathrm{BaO}-\mathrm{B}_{2} \mathrm{O}_{3}$ -
$\mathrm{SiO}_{2}$ systems. It should be mentioned that according to the data obtained [10] there is no immiscibility region found in the $\mathrm{MgO}-\mathrm{B}_{2} \mathrm{O}_{3}-\mathrm{SiO}_{2}$ system compared with the previous data [47] mentioned on Fig. (1) as circles in the other concentration areas where such phenomenon was observed.

\section{MODELING OF THERMODYNAMIC PROPERTIES OF OXIDE GLASSES AND MELTS}

The values of thermodynamic functions in the glasses and melts of the binary and multicomponent oxide systems found by the high temperature mass spectrometric method that were discussed above were used for modeling based on semi-empirical approaches by Kohler $[1-3,6,48]$ and Wilson $[1,3,4,6,48]$ as well as based on statistic thermodynamic methods such as the general lattice theory of associated solutions (GLTAS) [1, 8-10,33, 49, 50] and its particular case the theory of the ideal associated solutions $[8$, 20]. These approaches on one hand allowed to illustrate the opportunity of the prediction of thermodynamic properties of glasses and melts with the purpose of obtaining new materials with the properties required and on the other hand allowed to find the correlation between thermodynamic properties of glasses and melts and the features of their structural description $[1,8-10,33,49,50]$.

While in the theory of ideal associated solutions one can obtain information on the quantity of associates of the given type formed over the indicated concentration range, the generalized lattice theory of associated solutions makes it possible to calculate the relative numbers of bonds formed in the melts and to reveal the relationship between the values of thermodynamic functions and the structure of melt [51].

The generalized lattice theory of associated solutions was successfully applied earlier for the calculation of thermodynamic properties of $\mathrm{B}_{2} \mathrm{O}_{3}-\mathrm{GeO}_{2}, \mathrm{~B}_{2} \mathrm{O}_{3}-\mathrm{SiO}_{2}, \mathrm{GeO}_{2}$ $\mathrm{SiO}_{2}, \mathrm{~B}_{2} \mathrm{O}_{3}-\mathrm{GeO}_{2}-\mathrm{SiO}_{2}$ and $\mathrm{CaO}-\mathrm{SiO}_{2}$ glasses and melts [1, 52-56, 39], respectively. The further development of this theory for the calculation of thermodynamic properties was carried out for the ternary systems with one oxide-modifier and one glass-forming oxide such as the $\mathrm{CaO}-\mathrm{Al}_{2} \mathrm{O}_{3}-\mathrm{SiO}_{2}$, $\mathrm{CaO}-\mathrm{TiO}_{2}-\mathrm{SiO}_{2}$ and $\mathrm{BaO}-\mathrm{TiO}_{2}-\mathrm{SiO}_{2}$ systems $[8,33,49]$ and with one oxide-modifier and two glass-forming oxides such as the $\mathrm{Na}_{2} \mathrm{O}-\mathrm{B}_{2} \mathrm{O}_{3}-\mathrm{SiO}_{2}[22,57]$ and $\mathrm{Cs}_{2} \mathrm{O}-\mathrm{B}_{2} \mathrm{O}_{3}-\mathrm{SiO}_{2}[9,58$, 59] systems. The relative numbers of various types of bonds formed in these melts when the second coordination spheres were taken into consideration as a function of composition were calculated based on GLTAS.

Using this approach the different levels of deviations from the ideality in the melts studied were clarified. It should be underlined also that the relative numbers of various types of bonds formed in glasses and melts of the $\mathrm{B}_{2} \mathrm{O}_{3}-\mathrm{SiO}_{2}$ system when the second coordination spheres were taken into consideration as a function of composition were calculated based on GLTAS were in agreement with the same values obtained by IR-spectroscopy [52].

As well known the various approaches were used for the calculation thermodynamic properties of the $\mathrm{CaO}-\mathrm{Al}_{2} \mathrm{O}_{3}-$ $\mathrm{SiO}_{2}$ system such as the Monte-Carlo method [60-62], the sublattice model using thermo chemical data base Thermocalc [63], the thermodynamic model by Berman and Brown [64], the polymeric model $[65,66]$, the model of 


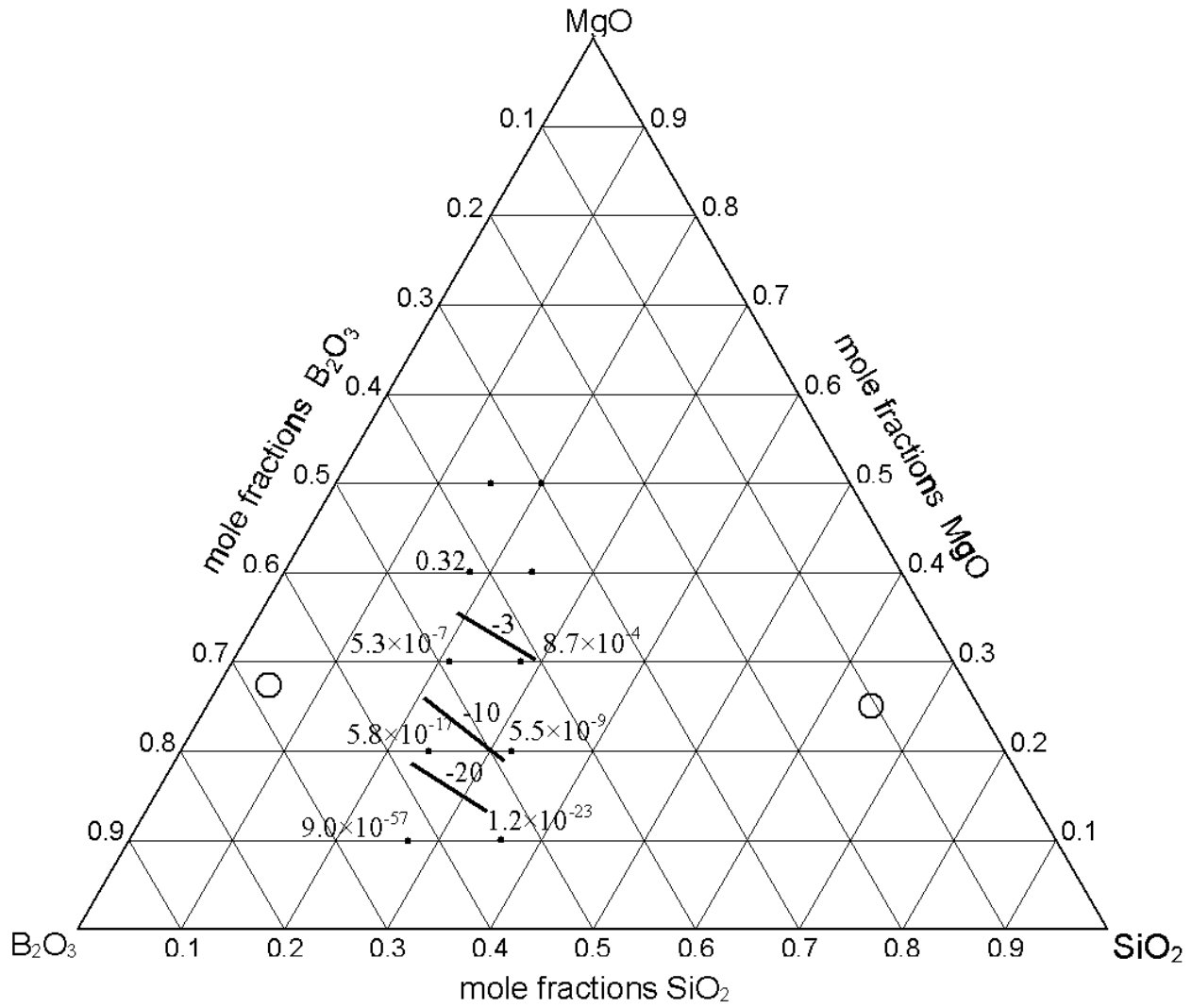

Fig. (1). The $\mathrm{MgO}$ activities and the lines of the logarithm of the $\mathrm{MgO}$ isoactivities in the $\mathrm{MgO}-\mathrm{B}_{2} \mathrm{O}_{3}-\mathrm{SiO}_{2}$ system at the temperature $1573 \mathrm{~K}$ [10]. "O" are indicated the compositions corresponding to liquids in the two phase region according to [47]: left point at the temperature 1453 $\mathrm{K}$ and the right point at the temperature $1573 \mathrm{~K}$.

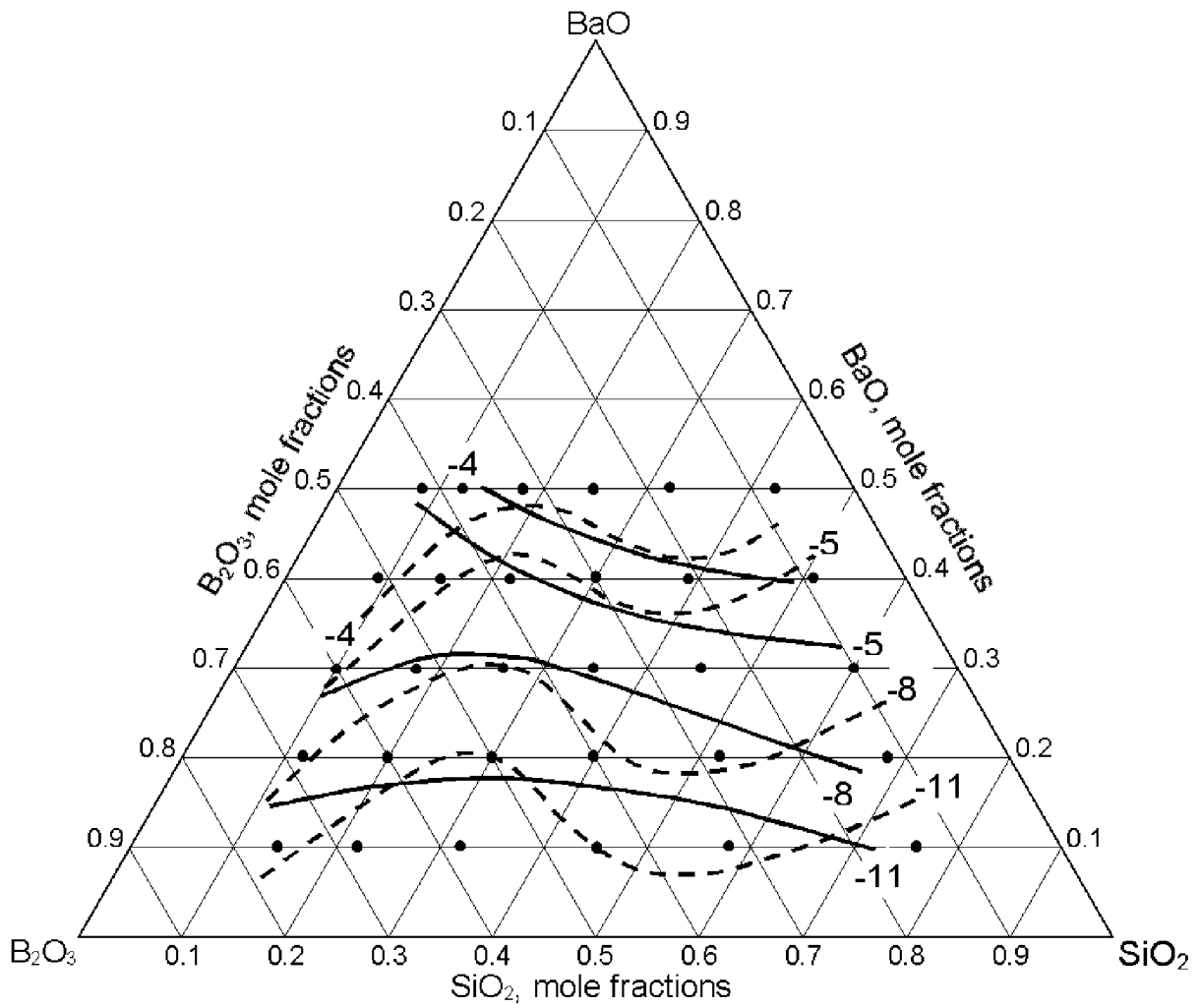

Fig. (2). The $\mathrm{BaO}$ isoactivities lines in melts of the $\mathrm{BaO}-\mathrm{B}_{2} \mathrm{O}_{3}-\mathrm{SiO}_{2}$ system at the temperature $1650 \mathrm{~K}$ : solid lines are results of modeling using GLTAS and dotted lines are the experimental data obtained by the Knudsen effusion mass spectrometric method [27, 29, 30]. 


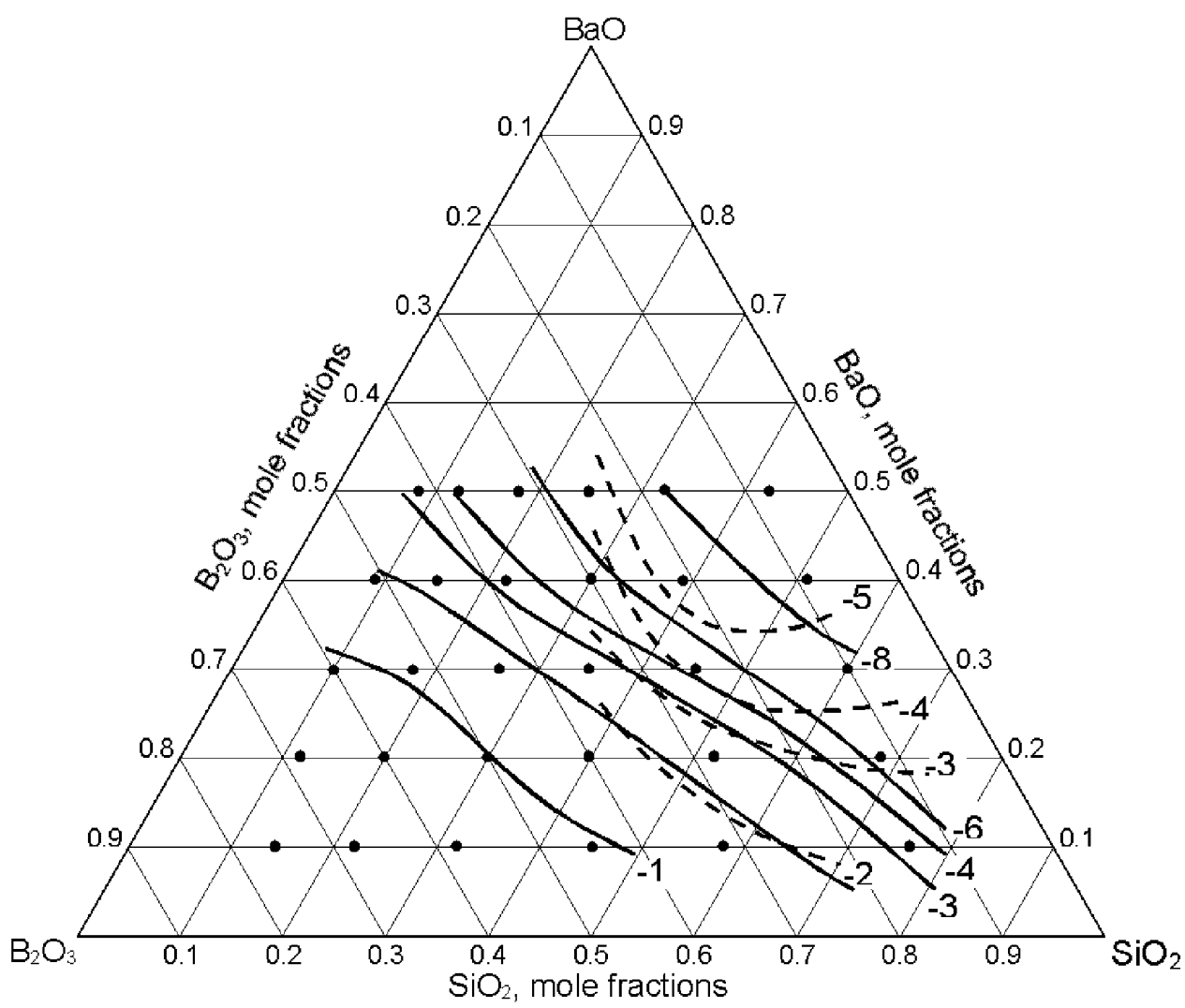

Fig. (3). The $\mathrm{B}_{2} \mathrm{O}_{3}$ isoactivities lines in melts of the $\mathrm{BaO}-\mathrm{B}_{2} \mathrm{O}_{3}-\mathrm{SiO}_{2}$ system at the temperature $1650 \mathrm{~K}$ : solid lines are results of modeling using GLTAS and dotted lines are the experimental data obtained by the Knudsen effusion mass spectrometric method [27, 29, 30].

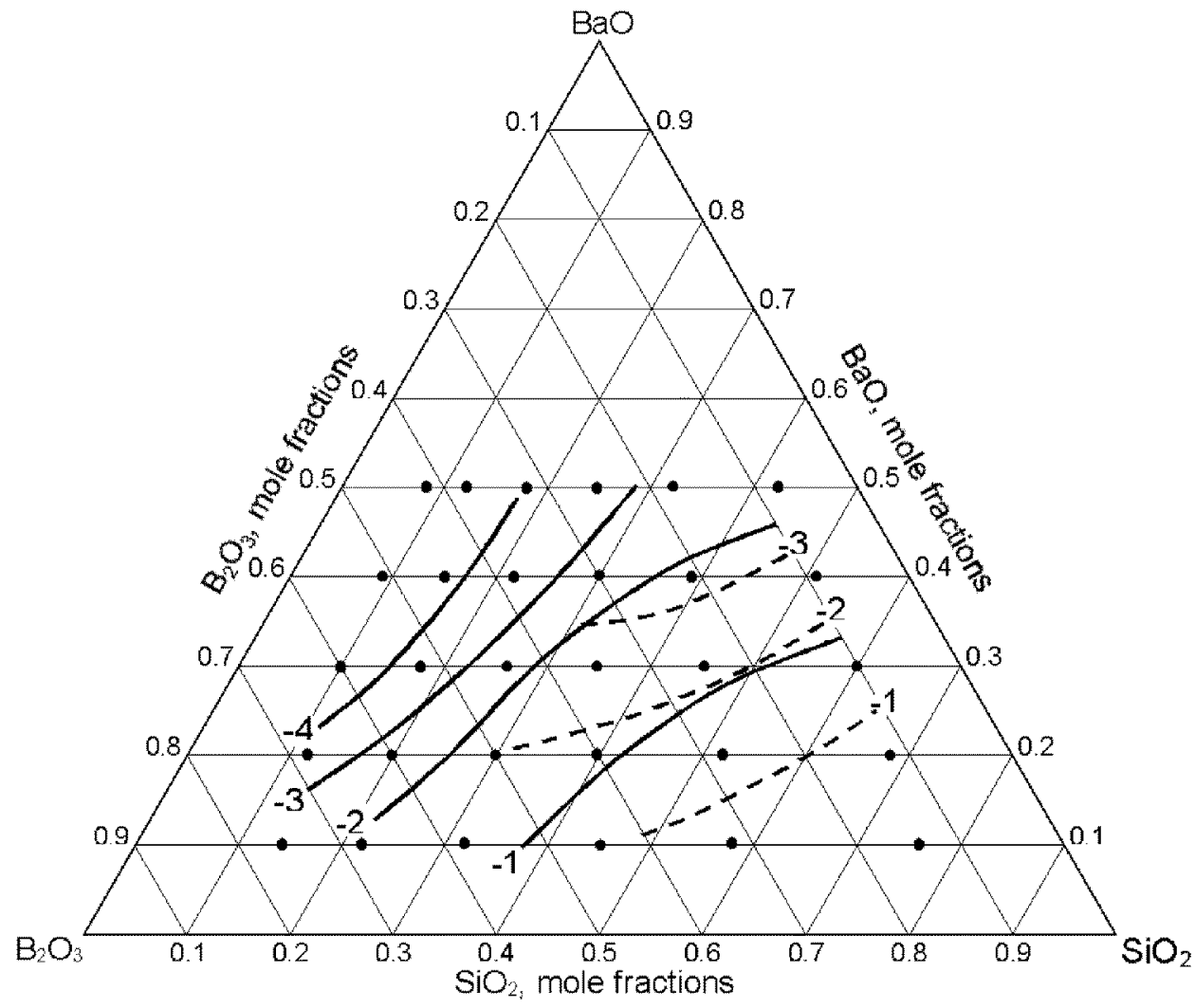

Fig. (4). The $\mathrm{SiO}_{2}$ isoactivities lines in melts of the $\mathrm{BaO}-\mathrm{B}_{2} \mathrm{O}_{3}-\mathrm{SiO}_{2}$ system at the temperature $1650 \mathrm{~K}$ : solid lines are results of modeling using GLTAS and dotted lines are the experimental data obtained by the Knudsen effusion mass spectrometric method [27, 29, 30]. 


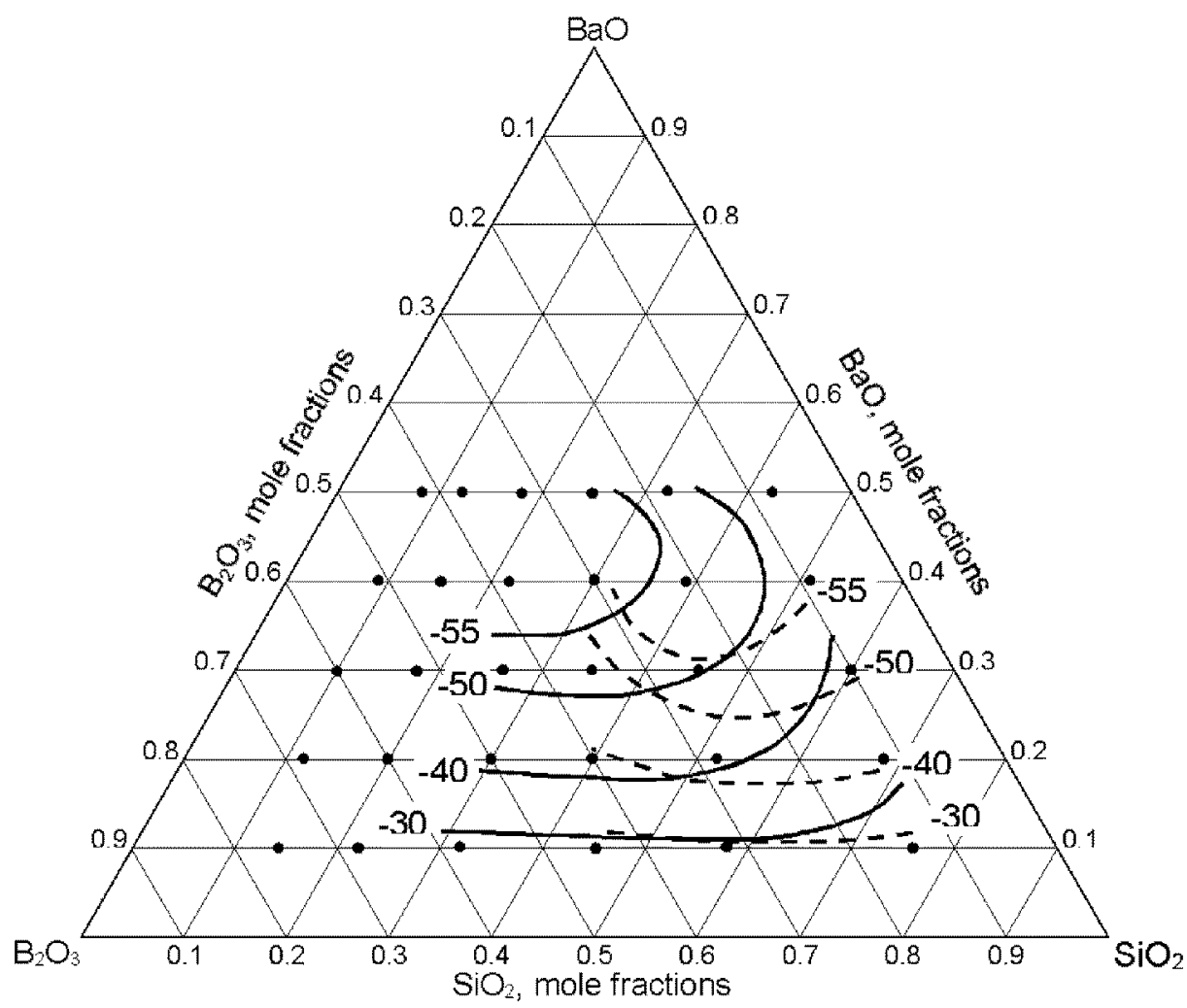

Fig. (5). The lines with the constant values of Gibbs energy of formation in melts of the $\mathrm{BaO}-\mathrm{B}_{2} \mathrm{O}_{3}-\mathrm{SiO}_{2}$ system at the temperature $1650 \mathrm{~K}$ : solid lines are results of modeling using GLTAS and dotted lines are the experimental data obtained by the Knudsen effusion mass spectrometric method $[27,29,30]$.

"central atoms" [67], the quasi-chemical model with some modifications [68], the quasi-chemical model using thermo chemical data base FACT $[69,70]$ and the molecular regular solution model [71]. Compared with the models indicated the approach under consideration have the following original features.

In the lattice theories the structural elements are situated in the sites of the hypothetical lattice of the melt closed to the crystal. Description of the peculiarities of the melt from the point of view of the coordination number and the lattice geometry allows taking into consideration the strong interactions of components or the structural elements. In that case the size and the shape of the molecules are considered as well as the possibility of the formation of associates. Introduction for every pair the various groups of three energetic interaction parameters in the melt allows using the quasi-chemical approximation based on the statistical approaches for the description the lattice models.

First, the basic ideas of GLTAS will be outlined following Barker [72]. This theory is based on the quasichemical approximation from which the numbers of interactions of various types in the equilibrium configuration of the system (melt)are deduced. Some structural information is required to choose a simulation model, i.e. a lattice with appropriate coordination number $z$ and structural units $A, B, \ldots$ corresponding to the components of the system, which are regarded as molecules occupying $r_{A}, r_{B}, \ldots$ sites of the lattice. The surface of these 'molecules' is divided into $c_{A}, c_{B}, \ldots$ contact points in accordance with the number of neighboring sites:
$c_{A}=r_{A} z-2 r_{A}+2$

A system of equations for a set of the auxiliary unknown variables $X_{\mu}^{A}$ is then formulated:

$X_{\mu}{ }^{A} \sum \eta_{\mu \nu}{ }^{A B} X_{v}{ }^{B}=Q_{\mu}{ }^{A} x_{A} / 2$

where $x_{A}$ is the mole fraction of the A component, $Q_{\mu}{ }^{A}$ is the number of $\mu$-type contact point of the A component, $\eta_{\mu \nu}{ }^{A B}$ is the energy parameters of the model related to free energy of exchange $\mathrm{U}_{\mu \nu}{ }^{\mathrm{AB}}$ of the $\mu$ - and $v$-type contact points of the $\mathrm{A}$ and $B$ structural units as $\eta_{\mu v}{ }^{A B}=\exp \left(-U_{\mu \nu}{ }^{A B} / k T\right)$. The number of the unknowns $X_{\mu}{ }^{A}$ is equal to the number of different types of contact points and hence to the number of equations (2). For a particular composition and a selected set of energy parameters $\eta_{\mu v}{ }^{A B}$ system (2) may be solved and the values of $\mathrm{X}_{\mu}{ }^{\mathrm{A}}$ found. Substitution of these values into eqn. (3)

$N_{\mu \nu}{ }^{A B}=2 X_{\mu}{ }^{A} X_{v}{ }^{B} \eta_{\mu v}{ }^{A B} N,\left[{ }^{\mathrm{A}}\right] \neq\left[{ }^{B}{ }^{B}\right]$

where $N_{\mu \nu}{ }^{A B}$ is the number of the $\mu$ - and $v$-type contact points of the $A$ and $B$ structural units, respectively, and $N$ is the total number of the particles in the system, allows to calculate the relative numbers of bonds of various types.

The energy parameters $\eta_{\mu \nu}{ }^{A B}$ may be determined by the best-fit procedure using the appropriate experimental data. The values of the excess chemical potential of the components derived in GLTAS are

$\Delta \mu^{E}{ }_{A}=R T\left[\sum Q_{\mu}{ }^{A} \ln \left(X_{\mu}^{A} / X_{\mu}^{A p} / x_{A}\right)+r_{A}(z / 2-1) \ln \left(\sum r_{i} x_{i} / r_{A}\right)\right]$

where $X_{\mu}^{A p}$ is the solution of system (2) for pure component $A$. The optimal set of energy parameters may be chosen by multiple substitutions of their trial values into (4) and 


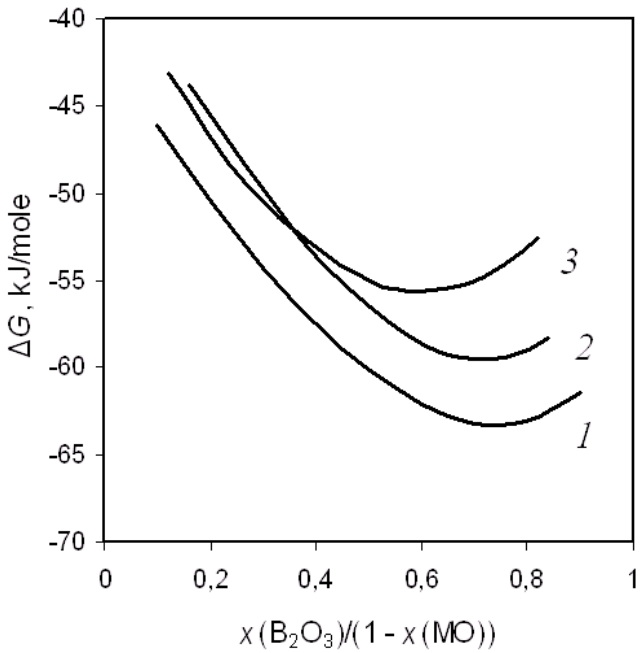

Fig. (6). The values of the Gibbs energies in the melts of the $\mathrm{CaO}$ $\mathrm{B}_{2} \mathrm{O}_{3}-\mathrm{SiO}_{2}(1), \mathrm{SrO}-\mathrm{B}_{2} \mathrm{O}_{3}-\mathrm{SiO}_{2}(2)$ and $\mathrm{BaO}-\mathrm{B}_{2} \mathrm{O}_{3}-\mathrm{SiO}_{2}$ (3) systems in the temperature range $1650-1800 \mathrm{~K}$ calculated according to GLTAS [50] at the mole fraction of $\mathrm{SiO}_{2}=0.50$ as a function of the melt concentration.

comparison of the resulting $\Delta \mu^{E}(x)$ with the experimental dependencies.

Compared with the previous studies of modeling thermodynamic properties of glasses and melts that were carried out using GLTAS in the $\mathrm{B}_{2} \mathrm{O}_{3}-\mathrm{GeO}_{2}, \mathrm{~B}_{2} \mathrm{O}_{3}-\mathrm{SiO}_{2}$, $\mathrm{GeO}_{2}-\mathrm{SiO}_{2}, \mathrm{~B}_{2} \mathrm{O}_{3}-\mathrm{GeO}_{2}-\mathrm{SiO}_{2}, \mathrm{CaO}-\mathrm{SiO}_{2}, \mathrm{CaO}-\mathrm{Al}_{2} \mathrm{O}_{3}-\mathrm{SiO}_{2}$, $\mathrm{CaO}-\mathrm{TiO}_{2}-\mathrm{SiO}_{2}, \quad \mathrm{BaO}-\mathrm{TiO}_{2}-\mathrm{SiO}_{2}, \quad \mathrm{Na}_{2} \mathrm{O}-\mathrm{B}_{2} \mathrm{O}_{3}-\mathrm{SiO}_{2}$ and $\mathrm{Cs}_{2} \mathrm{O}-\mathrm{B}_{2} \mathrm{O}_{3}-\mathrm{SiO}_{2}$ systems some improvements of the model and the approaches of calculation were suggested $[10,50]$ during investigation of melts in the $\mathrm{CaO}-\mathrm{B}_{2} \mathrm{O}_{3}-\mathrm{SiO}_{2}$, SrO$\mathrm{B}_{2} \mathrm{O}_{3}-\mathrm{SiO}_{2}, \mathrm{BaO}-\mathrm{B}_{2} \mathrm{O}_{3}-\mathrm{SiO}_{2}$ and $\mathrm{PbO}-\mathrm{B}_{2} \mathrm{O}_{3}$ systems.

As a further development of GLTAS applicability of this model was tested to borosilicate melts containing alkalineearth oxides $\mathrm{CaO}, \mathrm{SrO}$, and $\mathrm{BaO}$. Nevertheless, in our opinion, even without any further fundamental development of GLTAS, simply by a modification of computational procedure, the results may be improved considerably. Two of such optional algorithms were tested and reported in [50].

As and example of such calculation of thermodynamic properties in the ternary borosilicate melts containing alkaline-earth oxides let us consider the $\mathrm{BaO}-\mathrm{B}_{2} \mathrm{O}_{3}-\mathrm{SiO}_{2}$ systems. The following structural model was accepted for the description of these melts: on a 3-coordinated lattice structural units $\mathrm{B}_{2} \mathrm{O}_{3}, \mathrm{SiO}_{2}$, and $\mathrm{BaO}$ are placed; $\mathrm{BaO}$ occupies one site of the lattice, $\mathrm{B}_{2} \mathrm{O}_{3}$ and $\mathrm{SiO}_{2}$ - two sites each. The selected contact points on the surface of a structural unit refer either to its element or to its oxygen atom. It is considered that all chemical bonds are realized through atoms of oxygen and non-bridging oxygen do not exist in the melt.

To simplify the notation numbers $1,2,3$ in the indices will denote the structural units $\mathrm{SiO}_{2}, \mathrm{~B}_{2} \mathrm{O}_{3}$, and $\mathrm{BaO}$, respectively, and symbols of elements will indicate the type of contact point to which the given value refers. (e.g., $1 \mathrm{O}$ is the oxygen contact point of the structural unit $\mathrm{SiO}_{2}$ etc). Thus, $r_{1}=r_{2}=2, r_{3}=1$. The numbers of contact points were taken as follows: $Q_{1 \mathrm{Si}}=2, Q_{1 \mathrm{O}}=2, Q_{2 \mathrm{~B}}=2, Q_{2 \mathrm{O}}=2, Q_{3 \mathrm{Ba}}=$ $2, Q_{30}=1$.
In comparison with the previous calculations of thermodynamic properties based on GLTAS that were done in the glass-forming melts $[1,8,9,22,33,39,49,52-56,58$, 59] because the non-linear system of equations (2) was symmetrical with respect to its diagonal elements, that is $\eta_{i-k}$ $=\eta_{k-I}$, the other computational procedure was suggested [50]. Hence it can be written in a compact form as a product of matrix $\mathrm{H}=\left\{\eta_{i-k}\right\}$ of the coefficients of the system and vector $\mathrm{X}=\left(X_{1 \mathrm{Si}}, X_{1 \mathrm{O}}, X_{2 \mathrm{~B}}, X_{2 \mathrm{O}}, X_{3 \mathrm{Ba}}, X_{3 \mathrm{O}}\right)^{\mathrm{T}}$ of unknown variables $\left({ }^{\mathrm{T}}\right.$ denotes transposition):

$(\mathrm{H} \mathrm{X})^{\mathrm{T}} \mathrm{X}=1 / 2 \mathrm{Q}$,

where vector $\mathrm{Q}$ is $\left(x_{1} Q_{1 \mathrm{Si}}, x_{1} Q_{1 \mathrm{O}}, x_{2} Q_{2 \mathrm{~B}}, x_{2} Q_{2 \mathrm{O}}, x_{3} Q_{3 \mathrm{Ba}}\right.$, $\left.x_{3} Q_{30}\right)^{\mathrm{T}}, x_{i}$ is the content of the component $i$ in the melt, and matrix $\mathrm{H}$ has the form:

$\mathcal{c}=\left|\begin{array}{cccccc}1 & \varsigma_{1 \mathrm{Si}-1 \mathrm{O}} & 1 & \varsigma_{1 \mathrm{Si}-2 \mathrm{O}} & 1 & \varsigma_{1 \mathrm{Si}-3 \mathrm{O}} \\ \varsigma_{1 \mathrm{Si}-1 \mathrm{O}} & 1 & \varsigma_{1 \mathrm{O}-2 \mathrm{~B}} & 1 & \varsigma_{1 \mathrm{O}-3 \mathrm{Ba}} & 1 \\ 1 & \varsigma_{1 \mathrm{O}-2 \mathrm{~B}} & 1 & \varsigma_{2 \mathrm{~B}-2 \mathrm{O}} & 1 & \varsigma_{2 \mathrm{~B}-3 \mathrm{O}} \\ \varsigma_{1 \mathrm{Si}-2 \mathrm{O}} & 1 & \varsigma_{2 \mathrm{~B}-2 \mathrm{O}} & 1 & \varsigma_{2 \mathrm{O}-3 \mathrm{Ba}} & 1 \\ 1 & \varsigma_{1 \mathrm{O}-3 \mathrm{Ba}} & 1 & \varsigma_{2 \mathrm{O}-3 \mathrm{Ba}} & 1 & \varsigma_{3 \mathrm{Ba}-3 \mathrm{O}} \\ \varsigma_{1 \mathrm{Si}-3 \mathrm{O}} & 1 & \varsigma_{2 \mathrm{~B}-3 \mathrm{O}} & 1 & \varsigma_{3 \mathrm{Ba}-3 \mathrm{O}} & 1\end{array}\right|$

$\mathrm{n}$ this notation eqns. (4) for the excess chemical potentials are:

$\Delta \mu^{E}{ }_{1}=R T\left(2 \ln \left(X_{1 \mathrm{Si}} / X_{1 \mathrm{Si}}^{\mathrm{p}} / x_{1}\right)+2 \ln \left(X_{1 \mathrm{O}} / X_{1 \mathrm{O}} / x_{1}\right)+\ln \left(\left(x_{1}+x_{2}+1\right)\right.\right.$ /2))

$\Delta \mu_{2}^{E}=R T\left(2 \quad \ln \left(X_{2 \mathrm{~B}} / X_{2 \mathrm{~B}}{ }^{\mathrm{p}} / x_{2}\right)+2 \ln \left(X_{2 \mathrm{O}} / X_{2 \mathrm{O}} \mathrm{p} / x_{2}\right)+\ln \left(\left(x_{1}+x_{2}+1\right)\right.\right.$ /2))

$\Delta \mu^{E}{ }_{3}=R T\left(2 \quad \ln \left(X_{3 \mathrm{Ba}} / X_{3 \mathrm{Ba}}{ }^{\mathrm{p}} /\left(1-x_{1}-x_{2}\right)\right)+\ln \left(X_{3 \mathrm{O}} / X_{30} \mathrm{p} /\left(1-x_{1}-x_{2}\right)\right)\right.$ $\left.+1 / 2 \ln \left(x_{1}+x_{2}+1\right)\right)$

where vector $\left\{X_{i k}^{\mathrm{p}}\right\}(k=\mathrm{Si}, \mathrm{B}, \mathrm{O}, \mathrm{Ba})$ is the solution of the system (5) for pure $i$-th component, i.e. for $x_{i}=1$.

Results of the modeling the $\mathrm{BaO}, \mathrm{B}_{2} \mathrm{O}_{3}, \mathrm{SiO}_{2}$ activities and the Gibbs energy in the melts of the $\mathrm{BaO}-\mathrm{B}_{2} \mathrm{O}_{3}-\mathrm{SiO}_{2}$ system at the temperature $1650 \mathrm{~K}$ the based on GLTAS according to the procedure described compared with the experimental data are given on Figs. (2-5).

The values of the Gibbs energies in the melts of the $\mathrm{CaO}$ $\mathrm{B}_{2} \mathrm{O}_{3}-\mathrm{SiO}_{2}, \mathrm{SrO}-\mathrm{B}_{2} \mathrm{O}_{3}-\mathrm{SiO}_{2}$ and $\mathrm{BaO}-\mathrm{B}_{2} \mathrm{O}_{3}-\mathrm{SiO}_{2}$ systems in the temperature range $1650-1800 \mathrm{~K}$ calculated as mentioned above at the mole fraction of $\mathrm{SiO}_{2}=0.50$ as a function of the melt concentration are presented on Fig. (6).

Variation of the relative numbers of bonds of different types $\mathrm{B}-\mathrm{O}[\mathrm{B}], \mathrm{Si}-\mathrm{O}[\mathrm{Si}], \mathrm{B}-\mathrm{O}[\mathrm{Si}], \mathrm{B}-\mathrm{O}[\mathrm{M}], \mathrm{Si}-\mathrm{O}[\mathrm{M}], \mathrm{M}-$ $\mathrm{O}[\mathrm{B}], \mathrm{M}-\mathrm{O}[\mathrm{Si}], \mathrm{Si}-\mathrm{O}[\mathrm{B}], \mathrm{Si}-\mathrm{O}[\mathrm{B}], \mathrm{M}-\mathrm{O}[\mathrm{M}]$; where $\mathrm{M}=\mathrm{Ca}$, $\mathrm{Sr}, \mathrm{Ba}$, in the melts of the $\mathrm{CaO}-\mathrm{B}_{2} \mathrm{O}_{3}-\mathrm{SiO}_{2}(1), \mathrm{SrO}-\mathrm{B}_{2} \mathrm{O}_{3}-$ $\mathrm{SiO}_{2}(2)$ and $\mathrm{BaO}-\mathrm{B}_{2} \mathrm{O}_{3}-\mathrm{SiO}_{2}$ (3) systems in the temperature range $1650-1800 \mathrm{~K}$ calculated according to GLTAS [50] at the mole fraction of $\mathrm{SiO}_{2}=0.50$ as a function of the melt concentration are given and compared on Figs. (7-9), respectively.

As follows from the comparison of the values of the Gibbs energies in the melts of the $\mathrm{CaO}-\mathrm{B} 2 \mathrm{O} 3-\mathrm{SiO} 2$ (1), SrO$\mathrm{B} 2 \mathrm{O} 3-\mathrm{SiO} 2$ (2) and $\mathrm{BaO}-\mathrm{B} 2 \mathrm{O} 3-\mathrm{SiO} 2$ (3) systems in the temperature range $1650-1800 \mathrm{~K}$ calculated according to GLTAS [50] at the mole fraction of $\mathrm{SiO} 2=0.50$ as a function of the melt concentration, Fig. (6), with the corresponding variations of the relative numbers of bonds of different types 


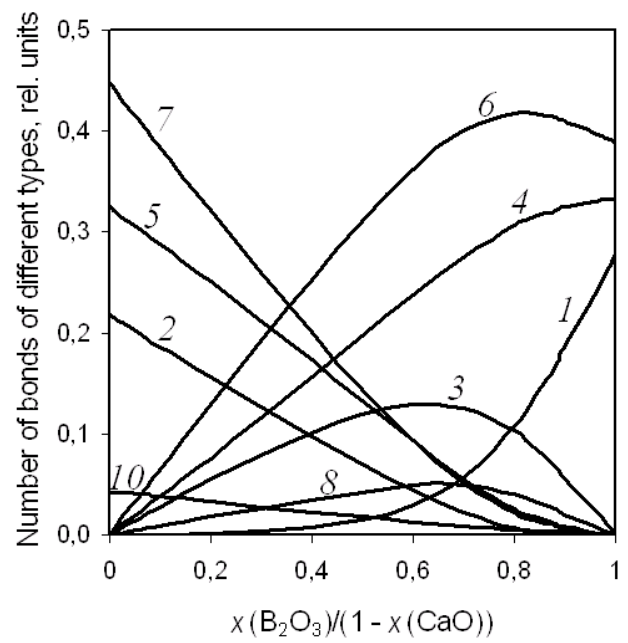

Fig. (7). Variation of the relative numbers of bonds of different types in the melts of the $\mathrm{CaO}-\mathrm{B}_{2} \mathrm{O}_{3}-\mathrm{SiO}_{2}$ system: $1-\mathrm{B}-\mathrm{O}[\mathrm{B}], 2-$ $\mathrm{Si}-\mathrm{O}[\mathrm{Si}], 3-\mathrm{B}-\mathrm{O}[\mathrm{Si}], 4-\mathrm{B}-\mathrm{O}[\mathrm{M}], 5-\mathrm{Si}-\mathrm{O}[\mathrm{M}], 6-\mathrm{M}-\mathrm{O}[\mathrm{B}], 7-$ $\mathrm{M}-\mathrm{O}[\mathrm{Si}], 8-\mathrm{Si}-\mathrm{O}[\mathrm{B}](\times 5), 9-\mathrm{Si}-\mathrm{O}[\mathrm{B}](\times 50), 10-\mathrm{M}-\mathrm{O}[\mathrm{M}](\times 5)$ in the temperature range $1650-1800 \mathrm{~K}$ calculated according to GLTAS [50] at the mole fraction of $\mathrm{SiO}_{2}=0.50$ as a function of the melt concentration.

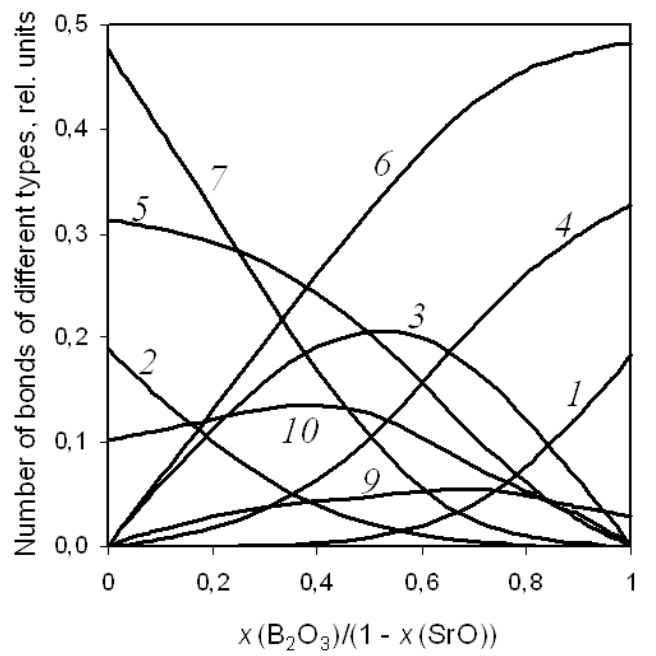

Fig. (8). Variation of the relative numbers of bonds of different types in the melts of the $\mathrm{SrO}-\mathrm{B}_{2} \mathrm{O}_{3}-\mathrm{SiO}_{2}$ system: $1-\mathrm{B}-\mathrm{O}[\mathrm{B}], 2-$ $\mathrm{Si}-\mathrm{O}[\mathrm{Si}], 3-\mathrm{B}-\mathrm{O}[\mathrm{Si}], 4-\mathrm{B}-\mathrm{O}[\mathrm{M}], 5-\mathrm{Si}-\mathrm{O}[\mathrm{M}], 6-\mathrm{M}-\mathrm{O}[\mathrm{B}], 7-$ $\mathrm{M}-\mathrm{O}[\mathrm{Si}], 8-\mathrm{Si}-\mathrm{O}[\mathrm{B}](\times 5), 9-\mathrm{Si}-\mathrm{O}[\mathrm{B}](\times 50), 10-\mathrm{M}-\mathrm{O}[\mathrm{M}](\times 5)$ in the temperature range $1650-1800 \mathrm{~K}$ calculated according to GLTAS [50] at the mole fraction of $\mathrm{SiO}_{2}=0.50$ as a function of the melt concentration.

in these melts obtained, Figs. (7-9), the structural description of these melts are very close to each other and illustrates the fact that their glass-forming network are strongly destroyed by oxide-modifier and contains the valuable fraction of the ionic bonds.

The accuracy of such structural interpretation of the melts behaviour in the $\mathrm{SrO}-\mathrm{B}_{2} \mathrm{O}_{3}-\mathrm{SiO}_{2}$ system using GLTAS was also recently confirmed by the result of the direct experimental studies of glasses in this system by the X-ray scattering method at big angels [73].

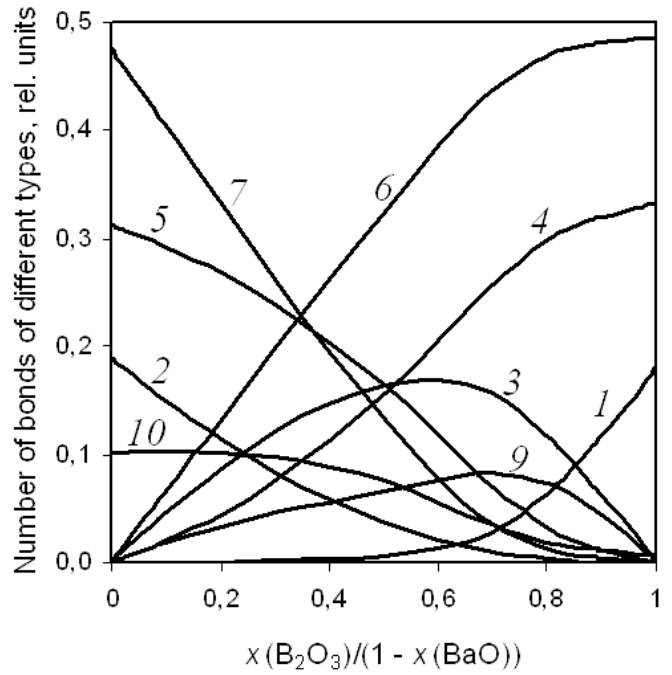

Fig. (9). Variation of the relative numbers of bonds of different types in the melts of the $\mathrm{BaO}-\mathrm{B}_{2} \mathrm{O}_{3}-\mathrm{SiO}_{2}$ system: $1-\mathrm{B}-\mathrm{O}[\mathrm{B}], 2-$ $\mathrm{Si}-\mathrm{O}[\mathrm{Si}], 3-\mathrm{B}-\mathrm{O}[\mathrm{Si}], 4-\mathrm{B}-\mathrm{O}[\mathrm{M}], 5-\mathrm{Si}-\mathrm{O}[\mathrm{M}], 6-\mathrm{M}-\mathrm{O}[\mathrm{B}], 7-$ $\mathrm{M}-\mathrm{O}[\mathrm{Si}], 8-\mathrm{Si}-\mathrm{O}[\mathrm{B}](\times 5), 9-\mathrm{Si}-\mathrm{O}[\mathrm{B}](\times 50), 10-\mathrm{M}-\mathrm{O}[\mathrm{M}](\times 5)$ in the temperature range $1650-1800 \mathrm{~K}$ calculated according to GLTAS [50] at the mole fraction of $\mathrm{SiO}_{2}=0.50$ as a function of the melt concentration.

Thus, this example is one more demonstration of the potential abilities of GLTAS for modeling thermodynamic properties of oxide glass-forming melts and for the consideration the correlations between them and their structure.

It should be noted also that thermodynamic functions obtained by the high temperature mass spectrometric method were used for the calculation of the phase diagrams in the $\mathrm{Rb}_{2} \mathrm{O}-\mathrm{B}_{2} \mathrm{O}_{3}$ system based on the theory of the ideal associated solutions $[74,75]$. In view of the uncertainties in the literature thermodynamic and phase diagram data in the case of the $\mathrm{Al}_{2} \mathrm{O}_{3}-\mathrm{SiO}_{2}$ system additional experimental studies of the component activities were carried out by the Knudsen effusion mass spectrometric method [42]. In the frame of the semi-empirical slag model based on these results [42] the model parameters were assigned [42, 76]. This enables reasonable predictions of thermodynamic properties in the melts of multicomponent alumosilicate slags as a functions of composition and temperature from binary data. The capability of this model to compute the component activities in the case of four component systems was also demonstrated. The applicability of this approach in estimating the viscosities of ternary silicate melts from the binaries using thermodynamic information of the ternary melt has been also demonstrated [76].

\section{APPLICATION OF THE APPROACHES DISCUSSED FOR THE DEVELOPMENT OF ADVANCED MATERIALS}

The general approaches discussed above to study vaporization processes and thermodynamic properties of oxide systems by high temperature mass spectrometric method as well as corresponding predictions of these processes the using acid-base concept and calculations of these properties based on various semi-empirical and 
statistical thermodynamic models had a wide spectrum of the practical applications [1]. The following important results may be mentioned in this connection:

- the development of various compositions of multicomponent borosilicate glasses with the low volatilities for the incorporation of nuclear wastes of middle level of activity $[3,77]$;

- the selection of the optimal conditions of preparation of some special glasses $[3,20]$;

- the application of borosilicate melts at the thermal production of ceramics [78];

- the study of vaporization processes of ceramics in the various gaseous atmospheres required for obtaining aircraft material [79-81];

- the study of vaporization processes and thermodynamic properties of slags containing heavy metals ( $\mathrm{Cr}$ and $\mathrm{V}$ ) for optimization of metallurgical processes and for its carrying out in the safety environmental conditions [82, 83].

Information on the vaporization processes and thermodynamic properties of glasses and melts in the $\mathrm{GeO}_{2}$ $\mathrm{SiO}_{2}$ system obtained by high temperature mass spectrometric method [53] was used for the calculation of the sample compositions of fluorine-germanosilicate glasses that were prepared by modified CVD process [84]. These results were patented $[85,86]$. The special compositions of zeolites with the properties required were prepared based on the results of studies of the vaporization processes and thermodynamic properties of melts in the $\mathrm{SnO}-\mathrm{ZnO}-\mathrm{B}_{2} \mathrm{O}_{3}$ system at high temperatures [87].

The problem of the interaction of nuclear fuel with the various types of concreate became extremely important after the accident at the Chernobyl nuclear power station. In this connection the vaporization processes and thermodynamic properties of the $\mathrm{UO}_{2}-\mathrm{ZrO}_{2}$ system and components in the various concrete compositions were studied at high temperatures $[3,48,88]$. Investigations of interactions processes of $\mathrm{SrO}$ with various oxide materials by high temperature mass spectrometric method allowed to suggest the composition of oxide material for the trap of nuclear reactor that was also patented in Russia [89] and Finland [90].

Among the high temperature mass spectrometric studies that were carried out for the solution the problems dealing with the various areas of application of oxide materials at high temperatures and involved in high temperature processing it will be reasonable to mention results on high temperature behaviour during interaction the oxide systems and materials with the other classes of the chemical compounds. Such new pioneering direction in high temperature material science was initiated during development of the new high temperature barrier coatings for space industry in particularly for the different parts of the space ship "Buran" $[91,92]$ that were working under various temperature conditions. For this purpose various compositions of borosilicate glasses were chosen together with $\mathrm{MoSi}_{2}$ [91] and with $\mathrm{BN}$ [92]. In the last case the probable weight losses of the coating studied during the flight conditions that were found by the Knudsen effusion mass spectrometric method were in agreement with the results obtained using the induction plasma generator.

Interaction processes at high temperatures between oxide and halide systems with the formation of the new unexpected vapour species such as $\mathrm{DyOF}$ and $\mathrm{Dy}_{2} \mathrm{OF}_{4}$ have the great importance in metallurgy, for example, for the preparation of alloys by electrolysis of oxygen containing salts in molten fluorides [93-95] or for the consideration of vaporization processes of fluxes as based on the $\mathrm{CaO}-\mathrm{CaCl}_{2}$ and $\mathrm{CaO}$ $\mathrm{CaF}_{2}$ systems studied in [96].

The further development of high temperature mass spectrometric studies considered may be connected also with the modifications of various types of mass spectrometers as were done using QMS 420 mass spectrometer that was applied for the Knudsen effusion studies [16, 97-99] or with the creation of new original methodologies of determination of physicochemical properties such as [100] where the changes in the refractive indexes of glasses in the $\mathrm{B}_{2} \mathrm{O}_{3}-\mathrm{SiO}_{2}$ system were calculated from the mass spectrometric experiment using the complete isothermal vaporization method.

\section{CONCLUSIONS}

1. The main regularities of the vaporization of oxide systems obtained by high temperature mass spectrometric method were discussed from the point of view of the acid-base concept.

2. Results on determination of thermodynamic functions that may be obtained by high temperature mass spectrometric method in some ternary silicate systems were considered taking into consideration the main requirements for the confirmation of their reliability.

3. Abilities of some semi-empirical and statistical thermodynamic approaches for modeling of thermodynamic properties of ternary glass-forming oxide melts were illustrated especially GLTAS.

4. The deviations from the ideality in the oxide systems studied were discussed based on GLTAS taking into attention the various types of bonds forming in glasses and melts when the second coordination sphere was taken into account.

5. The further application of high temperature mass spectrometry for the solution of the task high temperature materials science and processing may include the consideration of the following important questions:

- to find the regularities of vaporization processes of oxide systems and materials at high temperatures;

- to predict relative volatilities of oxide materials involved in different kind of high temperature technologies;

- to predict thermodynamic properties of oxide materials based on statistical thermodynamic approaches including the consideration of the correlation between thermodynamic properties studied and structure of these materials; 
to create data bases of thermodynamic properties of oxide systems and models for predictions:

a. the partial pressures of vapour species over oxide materials,

b. thermodynamic properties of oxide materials,

c. phase diagrams of the complex oxide systems;

- to improve the experimental approaches for the purpose indicated.

\section{CONFLICT OF INTEREST}

The authors confirm that this article content has no conflicts of interest.

\section{ACKNOWLEDGEMENTS}

The present study was carried out according to the financial support of the Russian Fund for Basic Research in the frame of the projects NN 07-03-238 and 10-03-705.

Author is very grateful to Dr. Technical Sciences A.L. Shilov for modeling of thermodynamic properties in borosilicate melts containing alkaline-earth oxides discussed in the present paper.

\section{REFERENCES}

[1] V.L. Stolyarova, and G.A. Semenov, Mass Spectrometric Study Of The Vaporization Of Oxide Systems. Wiley \& Sons: Chichester, 1994.

[2] V.L. Stolyarova, "High temperature mass spectrometric studies of the thermodynamioc properties of glass-forming systems", High Temperature Science, vol. 26, pp. 405-414, 1990.

[3] V.L. Stolyarova, "High temperature mass spectrometric study of oxide systems and materials", Rapid Communications in Mass Spectrometry, vol. 7, pp. 1022-1033, June 1993.

[4] V.L. Stolyarova, "Vaporization features of oxide systems studied by high temperature mass spectrometry", Journal of Nuclear Materials, vol. 247, pp. 7-10, January 1997.

[5] V.L. Stolyarova, "Mass spectrometric study of thermodynamic properties of oxide melts", Glass Physics and Chemistry, vol. 27, pp. 5-21, January 2001.

[6] V.L. Stolyarova, "Vaporization features of glass forming melts studied by high temperature mass spectrometry", Physics and Chemistry of Glasses, vol. 43C, pp. 330-338, 2002.

[7] V.L. Stolyarova, "High temperature mass spectrometric study of vaporization processes and thermodynamic properties of multicomponent oxide glasses", In: Proceedings of the XX ICG (International Congress on Glass) in Kyoto, 2004, pp. O-07-058 (1$6)$

[8] V.L. Stolyarova, and E.N. Plotnikov, "Vaporization processes and thermodynamic properties of oxide systems at high temperatures: experiment and modeling", Glass Physics and Chemistry, vol. 31, pp. 40-57, January 2005.

[9] V.L. Stolyarova, "Thermodynamic properties and structure of ternary silicate glass-forming melts: experimental studies and modeling", Journal of Non-Crystalline Solids, vol. 354, pp. 13731377, June-July 2008

[10] V.L. Stolyarova, "Thermodynamic properties and vaporization processes of ternary silicate systems studied by high temperature mass spectrometry", In: Seetharaman Seminar, 14-15 June 2010, Materials Processing Towards Properties, 2010, p. 11.

[11] M.M. Shultz, V.L. Stolyarova, and G.A.Semenov, "Thermodynamic functions in the melts of the $\mathrm{Na}_{2} \mathrm{O}-\mathrm{B}_{2} \mathrm{O}_{3}-\mathrm{GeO}_{2}$ system", Dokaldy Akademii nauk SSSR, vol. 246, pp. 154-156, January 1979.

[12] M.M. Shultz, V.L. Stolyarova, and G.A. Semenov, "Mass spectrometric study of thermodynamic properties and vaporization processes in the $\mathrm{Na}_{2} \mathrm{O}-\mathrm{B}_{2} \mathrm{O}_{3}-\mathrm{GeO}_{2}$ system", Journal of Non-Crystalline Solids, vols. 38-39, pp. 581-586, 1980.

[13] M.M. Shultz, V.L. Stolyarova, and G.A. Semenov, "Study of thermodynamic properties of melts in the $\mathrm{GeO}_{2}-\mathrm{B}_{2} \mathrm{O}_{3}$ by mass spectrometric method", Glass Physics and Chemistry, vol. 4, pp. 653-661, July 1978.

[14] G. Baret, "Etude Thermodynamique et Experimentale de Mélanges d'oxydes a Basse Temperature de Fluage pour l'electronique", These. Laboratoroire de thermodynamique et physicochemie metallurgiques, Grenoble, France, 1984.

[15] V.L. Stolyarova, A.L. Shilov, and S. Seetharaman, "Relative volatility of borate glasses and melts studied by high temperature mass spectrometry", In: Proceedings of XVII International Congress on Glass, 1995, vol. 7, pp. 155-160.

[16] V.L. Stolyarova, and S. Seetharaman, "Vaporization studies of oxide systems using a QMS-420 mass spectrometer", Vacuum, vol. 49, pp. 161-165, March 1998.

[17] S.I. Lopatin, V.L. Stolyarova, N.G. Tyurnina, and Z.G. Tyurnina, "Thermodynamic properties of melts in the $\mathrm{SrO}_{-} \mathrm{B}_{2} \mathrm{O}_{3}$ and $\mathrm{BaO}$ $\mathrm{B}_{2} \mathrm{O}_{3}$ systems", Russian Journal of General Chemistry, vol. 76, pp. 1761-1767, November 2006

[18] V.L. Stolyarova, "Vaporization features of glass forming oxide melts studied by high temperature mass spectrometry", In: Proceedings XIX International Congress on Glass, 2001, vol. 2, pp. 82-83.

[19] M.M. Shultz, V.L. Stolyarova, and I.Yu. Archakov, "Acid-base concept of vaporization of glass-forming melts", In: Proceesings. XV International Congress on Glass, 1989, vol. 1a, pp.126-131.

[20] V.L. Stolyarova, "Prediction of vaporization processes of oxide glasses and melts based on high temperature mass spectrometric data", In: Proceedings of XVII International Congress on Glass, 1995, vol. 6, pp. 108-114.

[21] I. Yu. Archakov, V.L. Stolyarova, and M.M. Shultz, "Relative volatility of borosilicate glasses: mass spectrometric study", Rapid Communications in Mass Spectrometry, vol. 12, pp. 1330-1334, October 1998.

[22] V. Stolyarova, G. Ivanov, S. Stolyar, and S.I. Lopatin, "Physicochemical properties of the $\mathrm{Na}_{2} \mathrm{O}-\mathrm{B}_{2} \mathrm{O}_{3}-\mathrm{SiO}_{2}$ system: calculation and experimental studies", In: Proceedings XIX International Congress on Glass, 2001, vol. 2, pp. 84-85.

[23] V.L. Stolyarova, G.G. Ivanov, and S.V. Stolyar, "Vaporization processes and thermodynamic properties of melts in the $\mathrm{Na}_{2} \mathrm{O}$ $\mathrm{B}_{2} \mathrm{O}_{3}-\mathrm{SiO}_{2}$ system", Glass Physics and Chemistry, vol. 28, pp. 160165, March 2002.

[24] V.L. Stolyarova, S.I. Lopatin, and E.N. Plotnikov, "Mass spectrometric study of thermodynamic properties of melts in the $\mathrm{Cs}_{2} \mathrm{O}-\mathrm{B}_{2} \mathrm{O}_{3}-\mathrm{SiO}_{2}$ system", Glass Physics and Chemistry, vol. 32, pp. 742-752, September 2006.

[25] S.I. Lopatin, S.M. Shugurov, and V.L. Stolyarova, "Thermodynamic properties of silicate glasses and melts. III. The $\mathrm{Rb}_{2} \mathrm{O}-\mathrm{B}_{2} \mathrm{O}_{3}-\mathrm{SiO}_{2}$ system", Russian Journal of General Chemistry, vol. 77, pp. 905-909, June 2007.

[26] V.L. Stolyarova, S.I. Lopatin, and S.M. Shugurov, "Thermodynamic properties of silicate glasses and melts. V. The $\mathrm{CaB}_{2} \mathrm{O}_{4}-\mathrm{CaSiO}_{3}$ and $\mathrm{Ca}_{2} \mathrm{~B}_{2} \mathrm{O}_{5}-\mathrm{CaSiO}_{3}$. systems", Russian Journal of General Chemistry, vol. 78, pp. 1639-1643, October 2008.

[27] V.L. Stolyarova, and S.I. Lopatin, "Thermodynamic properties of borosilicate melts containing alkaline-earth oxides", Vestnik $K G T U$, pp. 98-101, January 2010.

[28] V.L. Stolyarova, S.I. Lopatin, and A.L. Shilov, "Thermodynamic properties of silicate glasses and melts. VI. The $\mathrm{SrO}-\mathrm{B}_{2} \mathrm{O}_{3}-\mathrm{SiO}_{2}$ system", Russian Journal of General Chemistry, vol. 79, pp. 14221429, September 2009

[29] V.L. Stolyarova, and S.I. Lopatin, "Mass spectrometric study of the vaporization processes and thermodynamic properties in the $\mathrm{BaO}$ $\mathrm{TiO}_{2}-\mathrm{SiO}_{2}$ system", Glass Physics and Chemistry, vol. 31, pp. 179186, March 2005.

[30] Z.G. Tyurnina, S.I. Lopatin, and V.L. Stolyarova, "Thermodynamic properties of silicate glasses and melts. III. The $\mathrm{BaO}-\mathrm{B}_{2} \mathrm{O}_{3}-\mathrm{SiO}$ system", Russian Journal of General Chemistry, vol. 78, pp. 17-21, January 2008.

[31] V.L. Stolyarova, S.I. Shornikiv, and M.M. Shultz, "Hightemperature mass spectrometric study of the thermodynamic properties of the $\mathrm{CaO}-\mathrm{Al}_{2} \mathrm{O}_{3}-\mathrm{SiO}_{2}$ system", High Temperature Science and Materials, vol. 36, pp. 15-35, January 1996.

[32] V.L. Stolyarova, S.I. Lopatin, and S.V. Stolyar, "Determination of the $\mathrm{SiO}_{2}$ activity in the melts of the $\mathrm{CaO}-\mathrm{Al}_{2} \mathrm{O}_{3}-\mathrm{SiO}_{2}$ system by 
high temperature mass spectrometric method", Glass Physics and Chemistry, vol. 29, pp. 685-690, September 2003.

[33] V.L. Stolyarova, S.I. Lopatin, and E.N. Plotnikov, "Thermodynamic properties and vaporization processes of ternary glass-forming silicate systems $\mathrm{CaO}-\mathrm{Al}_{2} \mathrm{O}_{3}-\mathrm{SiO}_{2}, \mathrm{CaO}-\mathrm{TiO}_{2}-\mathrm{SiO}_{2}$ and $\mathrm{BaO}-\mathrm{TiO}_{2}-\mathrm{SiO}_{2}$ ", Physics and Chemistry of Glasses, vol. 46, pp. 119-127, March 2005.

[34] O. Ostrovski, G. Tranell, V.L. Stolyarova, M.M. Shultz, and A.I. Iskildyn," High-Temperature mass spectrometric study of the $\mathrm{CaO}-\mathrm{TiO}_{2}-\mathrm{SiO}_{2}$ system", High Temperature Materials and Processes, vol. 19, pp. 345-356, May 2000.

[35] V.L. Stolyarova, D.O. Zhegalin, and S.V. Stolyar, "Mass spectrometric study of thermodynamic properties of melts in the $\mathrm{CaO}-\mathrm{TiO}_{2}-\mathrm{SiO}_{2}$ system", Glass Physics and Chemistry, vol. 30, pp. 192-203, March 2004

[36] V.L. Stolyarova and S.I. Lopatin, "Mass spectrometric study of the vaporization processes and thermodynamic properties of components in the $\mathrm{BaO}-\mathrm{TiO}_{2}-\mathrm{SiO}_{2}$ system", Glass Physics and Chemistry, vol. 31, pp. 179-186, March 2005.

[37] V.I. Rakhimov, and V.L. Stolyarova," Thermodynamic regularities and reliability of high temperature mass spectrometric data for glass-forming oxide systems", In: Proceedings of the 1991 Dalian International Conference on Glass, 1991, pp. 38-41.

[38] V.L. Stolyarova, "Application of the Belton-Fruehan mass spectrometric method to study thermodynamic properties of oxide melts", In: Proceedings of the $5^{\text {th }}$ International Conference on Molten Slags, Fluxes and Salts'97, 1997, pp. 761-768.

[39] V.L. Stolyarova, S.I. Shornikov, G.G. Ivanov, and M.M. Shultz, "High Temperature Mass Spectrometric study of thermodynamic properties of the $\mathrm{CaO}-\mathrm{SiO}_{2}$ system", Journal of Electrochemical Society, vol. 138, pp. 3710-3714, December 1991.

[40] V.L. Stolyarova, S.I. Shornikov, G.G. Ivanov, and M.M. Shultz, "Mass Spectrometric Study of Vaporization Processes and Thermodynamic Properties in the $\mathrm{GeO}_{2}-\mathrm{P}_{2} \mathrm{O}_{5}$ System", Rapid Communications in Mass Spectrometry, vol. 4, pp. 510-512, June 1990.

[41] V.L. Stolyarova, A.L. Shilov, G.G. Ivanov, and M.M. Shultz, "High temperature mass spectrometric study of the $\mathrm{B}_{2} \mathrm{O}_{3}-\mathrm{Al}_{2} \mathrm{O}_{3}$ system at 1248-1850 K", Rapid Communications in Mass Spectrometry, vol. 9, pp. 1244-1251, July 1995.

[42] J. Bjorkvall, and V.L. Stolyarova, "A Knudsen cell mass spectrometric study of $\mathrm{Al}_{2} \mathrm{O}_{3}-\mathrm{SiO}_{2}$ melts", Rapid Communications in Mass Spectrometry, vol. 15, pp. 1-7, January 2001.

[43] V.L. Stolyarova, S.I. Lopatin, and V.V. Bondar, "Mass spectrometric study of the $\mathrm{Al}_{2} \mathrm{O}_{3}-\mathrm{SiO}_{2}$ system", Doklady Physical Chemistry, vol. 399, pp. 644-646, February 2004

[44] V.V. Bondar, S.I. Lopatin and V.L. Stolyarova, "High-temperature thermodynamic properties of the $\mathrm{Al}_{2} \mathrm{O}_{3}-\mathrm{SiO}_{2}$ system", Inorganic Materials, vol. 41, pp.434-441, April 2005.

[45] V.L. Stolyarova, S.I. Lopatin, and V.V. Bondar, " High temperature mass spectrometric study of the $\mathrm{MgO}-\mathrm{SiO}_{2}$ system", Doklady Physical Chemistry, vol. 399, pp. 82-84, January 2004.

[46] A.F. Khakhmotyko, T.B. Rudenko, V.L. Stolyarova, A.A. Vostryakov, and Yu. M. Smirnov, "Factual bases of physicochemical data", Izvestiya AN SSSR, pp. 221-223, April 1991.

[47] N.A. Toropov, V.P. Barzakovsky, V.V. Lapin, N.N. Kurzeva, and A.I. Boikova, Ed. Diagrammy sostoyaniya silikathykh system. Spravochnik. Troinye sistemy. (Phase diagrams of silicate systems. Refernce edition. Ternary systems). Nauka: Leningrad, 1972.

[48] V.L. Stolyarova, S.I. Shornikov, G.G. Ivanov, and M.M. Shultz, "High Temperature Mass Spectrometry study of multicomponent silicate system", In: Proceedings. 4th International Conference on Molten Slags and Fluxes, 1992, pp. 185-188.

[49] V.L. Stolyarova, "Calculation of thermodynamic properties of glass-forming silicate melts using the general lattice theory of associated solutions", In: Mathematical Modeling and Computer Simulation of Material Technologies. The Fourth International Conference MMT-2006, 2006, vol. 1, pp. 3-54-3-64.

[50] V.L. Stolyarova, and A.L. Shilov, "Modelling of thermodynamic properties and structure of borosilicate melts using high temperature mass spectrometric method", In: Mathematical Modeling and Computer Simulation of Materials Technologies. The Sixth International Conference. MMT-2010, 2010, pp. 1-56-1-64.

[51] N.A. Smirnova, Moleculyarnye teorii rastvorov. Khimiya: Leningrad, 1987.
[52] M.M. Shultz, G.G. Ivanov, V.L. Stolyarova, and B.A. Shakhmatkin, "Calculation of thermodynamic properties of glassforming melts in the $\mathrm{B}_{2} \mathrm{O}_{3}-\mathrm{GeO}_{2}$ and $\mathrm{B}_{2} \mathrm{O}_{3}-\mathrm{SiO}_{2}$ systems", Glass Physics and Chemistry, vol. 12, pp. 385-390, July 1986.

[53] M.M. Shultz, V.L. Stolyarova, and G.G. Ivanov, "Thermodynamic properties of melts and glasses in the $\mathrm{GeO}_{2}-\mathrm{SiO}_{2}$ system", Glass Physics and Chemistry, vol. 13, pp. 830-838, November 1987.

[54] M.M. Shultz, G.G. Ivanov, and V.L. Stolyarova, "Prediction of thermodynamic properties of the binary glassforming melts", Doklady AN SSSR, vol. 292, pp. 1198-2002, February 1987.

[55] V.L. Stolyarova, G.G. Ivanov, and M. M. Shultz, "Thermodynamic properties of glasses and melts of the borogermanosilica system", Doklady AN SSSR, vol. 305, pp. 383-386, January 1989.

[56] V.L. Stolyarova, G.G. Ivanov, and M. M. Shultz, "Mass spectrometric study of thermodynamic properties of melts in the $\mathrm{B}_{2} \mathrm{O}_{3}-\mathrm{GeO}_{2}-\mathrm{SiO}_{2}$ system", Glass Physics and Chemistry, vol. 17, pp. 689-697, September 1991.

[57] E. N. Plotnikov, and V.L. Stolyarova, "Modeling of thermodynamic properties of melts in the $\mathrm{Na}_{2} \mathrm{O}-\mathrm{B}_{2} \mathrm{O}_{3}-\mathrm{SiO}_{2}$ system based on the general lattice theory of associated solutions", Glass Physics and Chemistry, vol. 32, pp. 580-598, July 2006.

[58] E. N. Plotnikov, and V.L. Stolyarova, "Thermodynamic properties of glasses and melts in the $\mathrm{Cs}_{2} \mathrm{O}-\mathrm{B}_{2} \mathrm{O}_{3}-\mathrm{SiO}_{2}$ system calculated based on the general lattice theory of associated solutions", Glass Physics and Chemistry, vol. 32, pp. 251-264, March 2006.

[59] E. N. Plotnikov, and V.L. Stolyarova, "Modeling of thermodynamic properties of glass melts in the $\mathrm{Cs}_{2} \mathrm{O}-\mathrm{B}_{2} \mathrm{O}_{3}-\mathrm{SiO}_{2}$ system at $1020 \mathrm{~K}$ in the concentration range $0.06-0.50$ mole fractions $\mathrm{Cs}_{2} \mathrm{O}$ ", Glass Physics and Chemistry, vol. 32, pp. 753772, September 2006.

[60] C. Borgianni, and P. Granati, "Thermodynamic properties of silicates and of aluminosilicates from Monte-Carlo calculations", Metallurgical and Materials Transaction B, vol. 8, pp. 147-151, January 1977.

[61] O.I. Bukhtoyarov, Y. S. Shkolnik, L.A. Smirnov, and S.P. Kurlov, "Calculation of heat of mixing and structural elements of melts in the $\mathrm{CaO}-\mathrm{Al}_{2} \mathrm{O}_{3}-\mathrm{SiO}_{2}$ system by the Monte-Carlo method", Rasplavy, vol. 1, pp. 45-49, December 1987.

[62] O.I. Bukhtoyarov, Y. S. Shkolnik, L.A. Smirnov, and S.P. Kurlov, "Calculation of activities of components of melts in the $\mathrm{CaO}$ $\mathrm{Al}_{2} \mathrm{O}_{3}-\mathrm{SiO}_{2}$ system by the Monte-Carlo method", Rasplavy, vol. 2, pp. 99-101, July 1988.

[63] X. Wang, M. Hillert, and B. Sundman, A thermodynamic evaluation of the $\mathrm{Al}_{2} \mathrm{O}_{3}-\mathrm{CaO}-\mathrm{SiO}_{2}$ system. TRITA-MAC-0407. Materials Research Center of the Royal Institute of Technology: Stockholm, 1990.

[64] R.G. Berman, and T.H. Brown, "A thermodynamic model for multicomponent melts with application to the system $\mathrm{CaO}-\mathrm{Al}_{2} \mathrm{O}_{3}-$ $\mathrm{SiO}_{2}$ ", Geochimica et Cosmochimica Acta, vol. 48, pp. 661-678, April 1984.

[65] N.I. Zalomov, and V.N. Boronenkov, "Calculation of activities and ion composition of multicomponent silicate melts", Rasplavy, vol. 5, pp. 33-39, May 1991.

[66] V.K. Novikov, V.N. Nevidimovand G.A. Toporizhshev, "Comparison of the models of slag melts based on the example of calculation of component activities in multicomponent alumosilicate system", Rasplavy, vol. 5, pp.3-9, January 1991.

[67] P. Sastri, and A.K. Lahiri, "Central atoms" models for ternary silicate and alumosilicate melts", Metallurgical Transaction B, vol. 17B, pp. 105-110, January 1986.

[68] I.T. Sryvalin, and O.A. Esin, "Activities of components of the melt in the $\mathrm{CaO}-\mathrm{Al}_{2} \mathrm{O}_{3}-\mathrm{SiO}_{2}$ system", Izvestiya VUZov. Chernaya Metallurgia, pp. 10-12, August 1959.

[69] G. Eriksson and A.D. Pelton, " Critical evaluation and optimization of the thermodynamic properties and Phase diagrams of the $\mathrm{CaO}$ $\mathrm{Al}_{2} \mathrm{O}_{3}, \mathrm{Al}_{2} \mathrm{O}_{3}-\mathrm{SiO}_{2}$ and $\mathrm{CaO}-\mathrm{Al}_{2} \mathrm{O}_{3}-\mathrm{SiO}_{2}$ systems", Metallurgical Transactions B, vol. 24B, pp.807-816, October 1993.

[70] A.D. Pelton, "Thermodynamic modeling and phase equilibrium calculations in nuclear materials", Pure and Applied Chemistry, vol. 69, pp. 2245-2252, November 1997.

[71] O.B. Fabrichnaya and I. Nerad, "Thermodynamic properties of liquid phase in the $\mathrm{CaO} \cdot \mathrm{SiO} 2-\mathrm{CaO} \cdot \mathrm{Al} 2 \mathrm{O} 3 \cdot 2 \mathrm{SiO} 2-$ $2 \mathrm{CaO} \cdot \mathrm{A} 12 \mathrm{O} 3 \cdot \mathrm{SiO} 2$ system", Journal of European Ceramic Society, vol. 20, pp. 505-515, May 2000.

[72] J.A. Barker, "Cooperative Orientation Effects in Solutions", Journal of Chemical Physics, vol. 20, pp 1526-1532, October 1952. 
[73] V.V. Golubkov, N.G. Tyurnina, Z.G. Tyurnina, and V.L. Stolyarova, "About fluctuation structure of mohophase glasses in the $\mathrm{SrO}-\mathrm{B}_{2} \mathrm{O}_{3}-\mathrm{SiO}_{2}$ system", Glass Physics and Chemistry, vol. 35, pp. 601-611, September 2009.

[74] V.L. Stolyarova, and S.I. Lopatin, "Mass spectrometric study of thermodynamic properties of melts in the $\mathrm{Rb}_{2} \mathrm{O}-\mathrm{B}_{2} \mathrm{O}_{3}$ system", Glass Physics and Chemistry, vol. 30, pp. 204-211, March 2004.

[75] V.L. Stolyarova, and V.V. Gusarov, "Mass spectrometric study of glasses and melts in the $\mathrm{Rb}_{2} \mathrm{O}-\mathrm{B}_{2} \mathrm{O}_{3}$ System:Vaporization, Thermodynamics and Phase Diagram", In: Proceedings of the Mills Symposium on Molten Slags and Fluxes, 2002, pp. 495-500.

[76] J. Bjorkvall, Du Sichen, V.L. Stolyarova, and S. Seetharaman, ” A Model Description of the thermodynamic properties of multicomponent slags and its application to slag viscosities", Glass Physics and Chemistry, vol. 27, pp. 200-227, March 2001.

[77] M.M. Shultz, I. Y. Archkov, G.G. Ivanov, and V.L. Stolyarova, "The study of the evaporation of the multicomponent borosilicate glasses containing cesium oxide", Glastechnische Berichte Technology, vol. 68, pp. 326-331, January 1995.

[78] N.A. Luk'yanova, V.L. Stolyarova, T.S. Tzekhomskaya, and E.V. Churkina, "Some aspects of application of borosilicate melts during thermal synthesis of ceramic solids", Elektronnaya Tekhnika, Seria 6, Materials, pp. 65-67, December 1987.

[79] Yu. I Folomeikin, I.M. Demonis, E.N. Kablov, S.I. Lopatin, and V.L. Stolyarova, " Mass spectrometric study of vaporization processes of alumina with carbon", Doklady Physical Chemistry, vol. 399, pp. 795-798, June 2004

[80] Yu. I Folomeikin, S.I. Lopatin, and V.L. Stolyarova, "Study of vaporization of alumina in neutral and reduction conditions", Russian Journal of General Chemistry, vol. 76, pp. 1767-1772, November 2006.

[81] Yu. I Folomeikin, I.M. Demonis, E.N. Kablov, S.I. Lopatin, and V.L. Stolyarova, "Study of vaporization processes of $\mathrm{Al}_{2} \mathrm{O}_{3}$ over carbon at high temperatures", Glass Physics and Chemistry, vol. 32, pp. 265-270, March 2006.

[82] L.J. Wang, V.L. Stolyarova, S.I. Lopatin, and S. Seetharaman, "High-temperature mass spectrometric study of the vaporization processes in the system $\mathrm{CaO}-\mathrm{MgO}-\mathrm{Al}_{2} \mathrm{O}_{3}-\mathrm{Cr}_{2} \mathrm{O}_{3}-\mathrm{FeO}-\mathrm{SiO}_{2}$ ", Rapid Communications in Mass Spectrometry, vol. 23, pp. 2233-2239, July 2009 .

[83] H. Wang, V.L. Stolyarova, S.I. Lopatin, M.E. Kutuzova, and S. Seetharaman, "High temperature mass spectrometric study of the vaporization processes of $\mathrm{V}_{2} \mathrm{O}_{3}$ and vanadium-containing slags", Rapid Communications in Mass Spectrometry, vol. 24, pp. 24202430, August 2010. V. 24.

[84] A.G. Andreev, V.S. Ermakov, I.I. Krukov, M.K. Zibinogina, A.B. Shein, P.A. Zlobin, E.V. Kolobkova, and M.A. Eronyan, "Study of process of modified chemical vapour deposition during obtaining glass of the $\mathrm{SiO}_{2}-\mathrm{GeO}_{2}-\mathrm{F}$ system", Glass Physics and Chemistry, vol. 32, pp. 717-723, September 2006.

[85] M.A. Eronyan, M.K. Zibinogina, and P.A. Zlobin, "Method of high temperature chemical treatment of the glass surface", Russian Federation Patent № 2272003, MPK C03B37/075, 2006.

[86] M.A. Eronyan, M.K. Zibinogina, and L.G. Levit, "Method of manufacturing of fiber-optic guides maintained the polarization of irradiation", Russian Federation Patent No. 2272002, MPK C03B37/018, 2006.

[87] A.L. Shilov, S.I. Shornikov, A. Y. Archakov, G.G. Ivanov, V.L. Stolyarova, and M.M. Shultz, "Mass spectrometric study of vaporization processes and thermodynamic properties of melts in the $\mathrm{SnO}-\mathrm{ZnO}-\mathrm{P}_{2} \mathrm{O}_{5}$ system", Glass Physics and Chemistry, vol. 24, pp.568-574, September 1998.
[88] V.L. Stolyarova, A.L. Shilov, and M.M. Shultz, "Thermodynamic properties of the $\mathrm{UO}_{2}-\mathrm{ZrO}_{2}$ system studied by the isothermal mass spectrometric vaporization method", Journal of Nuclear Materials, vol. 247, pp. 41-45, January 1997.

[89] V.V. Gusarov, V.I. Almyashev, V.L. Stolyarova, V.B. Khabensky, S.V. Beshta, V.S. Granovsky, Yu.N. Aniskevich, E.V. Krushinov, S.A. Vitol, I.V. Saenko, E.D. Sergeev, V.V. Petrov, V.A. Tikhomirov, V.P. Migaly, A.N. Novikov, V.A. Mozherin, V.Ya. Sakkulin, A.N. Novikov, G.N. Salagina, E.A. and Shtern, "Oxide material of the melt trap of the active zone of nuclear reactor", Russian Federation Patent № 2192053, October 12, 2001.

[90] V.V. Gusarov, V.B. Khabensky, S.V. Beshta, V.S. Granovsky, V.I. Almyashev, E.V. Krushinov, S.A. Vitol, E.D. Sergeev, V.V Petrov, V.A. Tikhomirov, V.V. Bezlepkin, I.V. Kukhtevich, Yu.N Aniskevich, I.V. Sayenko, V.L. Stolyarova, V.P. Migal, V.A Mozherin, V.Ya. Sakulin, A.N. Novikov, G.N. Salagina, E.A. Shtern, and V.G. Asmolov, "Oxide material of the melt trap of the active zone of nuclear reactor", Finland Patent (Suomi-Finland. Patentii) No. 118445, November 15, 2007.

[91] M.M. Shultz, A.Y. Archakov, M.V. Sazonova, and V.L. Stolyarova, "Vaporization processes of borosilica glass melt and glass-silicide coating", Glass Physics and Chemistry, vol. 16, pp. 276-285, March 1990.

[92] V.L. Stolyarova, I. Y. Archakov, A.N. Gordeev, M.I. Yakushin, and M.M. Shultz, "Vaporization processes of borosilicate coatings studied by high temperature mass spectrometry and using an induction plasma generator", Rapid Communications in Mass Spectrometry”, vol. 7, pp. 127-131, January 1993.

[93] V.L. Stolyarova, and S. Seetharaman, "Mass spectrometric study of the vaporization processes and thermodynamic properties of the $\mathrm{DyF}_{3}-\mathrm{Dy}_{2} \mathrm{O}_{3}$ system", In: Rare earths. Science, Technology and Applications. III, R.G.Bautista, Ed. Minerals, Metals and Materials Society: Warrendale, Pennsylvania, 1997, pp. 23-33.

[94] V.L. Stolyarova, and S. Seetharaman, "High temperature mass spectrometric study of the vaporization processes in the $\mathrm{DyF}_{3}$ $\mathrm{Dy}_{2} \mathrm{O}_{3}$ system", Rapid Communications in Mass Spectrometry", vol. 10, pp.781-789, April 1996.

[95] V.L. Stolyarova, and S. Seetharaman, "High temperature mass spectrometric study of the thermodynamic properties of the $\mathrm{DyF}_{3}$ $\mathrm{Dy}_{2} \mathrm{O}_{3}$ system", Rapid Communications in Mass Spectrometry", vol. 12, pp.736-740, June 1998

[96] V.L. Stolyarova, S. Seetharaman, D. Svard, and G.A. Seemenov, "A high temperature mass spectrometric study of the vaporization processes of fluxes based on $\mathrm{CaO}-\mathrm{CaCl}_{2}$ and $\mathrm{CaO}-\mathrm{CaF}_{2}$ systems", Rapid Communications in Mass Spectrometry", vol. 12, pp. 13351343, October 1998.

[97] V.L. Stolyarova, Du Sichen, and S. Seetharaman, "Application of a QMG-420 mass spectrometer for high temperature studies", Vacuum, vol. 46, pp. 871-874, August-October 1995.

[98] A.L. Shilov, L.E. Holappa, and V.L. Stolyarova, "A Knudsen effusion high temperature assembly for a quadrupole QMS-420 mass spectrometer", Rapid Communications in Mass Spectrometry, vol. 11, pp.1425-1429, June 1997.

[99] A.L. Shilov, L.E. Holappa, and V.L. Stolyarova, "A high temperature mass spectrometric study of $\mathrm{Cu}-\mathrm{Mg}$ alloys", Rapid Communications in Mass Spectrometry, vol. 12, pp. 1133-1136, September 1998.

[100] M.S. Shikhalieva, and V.L. Stolyarova, "Study of refractive index of glasses in the $\mathrm{B}_{2} \mathrm{O}_{3}-\mathrm{SiO}_{2}$ system under isothermal vaporization", Journal of Optical Technology, vol. 70, pp. 69-71, January 2003.

This is an open access article licensed under the terms of the Creative Commons Attribution Non-Commercial License (http://creativecommons.org/licenses/ by-nc/3.0/) which permits unrestricted, non-commercial use, distribution and reproduction in any medium, provided the work is properly cited. 